\title{
Nahiv Yöntembiliminde Birincil Delillerin Tearuzu Olgusu ve Tercih Yöntemine Bir Bakış
}

\section{A Look at The Conflict Case of Primary Evidence and The Method of Preference in Nahiv Methodics}

\section{Mehmet Zahid Çokyürür}

Dr. Arș. Gör., Karamanoğlu Mehmetbey Üniversitesi, İslami İlimler Fakültesi, Arap Dili ve Belağatı Anabilim Dalı

Res. Assist. PhD., Karamanoğlu Mehmetbey University, Faculty of Divinity, Department of Arabic Langauge and Rhetoric

Karaman, Turkey

zahidcokyurur@gmail.com | https://orcid.org/0000-0002-2587-3882

Article Type / Makale Tipi

Research Article / Araştırma Makalesi

DOI: $10.33420 /$ marife.1009834
Article Information / Makale Bilgisi

Received / Geliş Tarihi: 14.10.2021

Accepted / Kabul Tarihi: 27.12.2021

Published / Yayın Tarihi: 30.12.2021

Cite as / Atıf: Çokyürür, Mehmet Zahid. "Nahiv Yöntembiliminde Birincil Delillerin Tearuzu Olgusu ve Tercih Yöntemine Bir Bakış". Marife 21/2 (2021): 1081-1107.

https://doi.org/10.33420/marife.1009834

Plagiarism / Intihal: This article has been reviewed by at least two referees and scanned via a plagiarism software. / Bu makale, en az iki hakem tarafından incelendi ve intihal içermediği teyit edildi.

\section{(c) $(1)(3)$}

Copyright / Telif Hakkl: "This article is an open access article distributed under the terms and conditions of the Creative Commons Attribution-NonCommercial-NoDerivatives 4.0 (CC BY-NC-ND 4.0) International License." / "Bu makale Creative Commons Alıntl-GayriTicari-Türetilemez 4.0 (CC BY-NCND 4.0) Uluslar arası Lisansı altında lisanslanmıştır." 


\section{Nahiv Yöntembiliminde Birincil Delillerin Tearuzu Olgusu ve Tercih Yöntemine Bir Bakış}

\section{Özet}

Herhangi bir ilim dalındaki işlevsel bir metodoloji oluşturma çabası, o ilim dalında tutarlı ve genel geçer kavram, kuram ve kurallara erişme gayesinin açık göstergesidir. Aynı çaba ve gayeye Arap dilinde de șahit olunmuștur. Arap dilbiliminde tutarlı ve genel geçer dil kurallarına ulașabilmek için fonksiyonel bir metodoloji tesis etme ihtiyacı kendini hissettirmiş olmalı ki; bu meyanda tıpkı hadis ve fikıh usulü ilimlerinde olduğu gibi İbn Cinnî, Kemâleddin el-Enbârî ve Suyûtî gibi Arap dili bilginlerinin özenli çabaları neticesinde nahiv usulü ilmi teșekkül etmiştir. Nitekim mantıkî ve usulî kavram, tahlil ve yaklaşımların Arap dilbiliminde İbn Cinnî ile birlikte yoğun bir șekilde görülmeye bașlaması bu durumu destekler niteliktedir. Yine Kemâleddîn el-Enbârî̀nin usule dair "el-İğrâb fí cedeli'l i'râb" adlı eserinin önsözünde ilmî çevrenin ricası üzerine eserini telif ettiğinin altını çizmesi, diğer bir güçlü veri olarak karşımızda durmaktadır. İlim dünyasına birçok dalda eser hediye etmiş olan Suyûtî ise "elIktirâh" unvanlı meșhur eseri özelinde, nahiv usulü ilmini biraz daha geliștirme ve daha derli toplu hale getirme vazifesini üstlenmiștir. Her ne kadar nahiv usulüne dair Sîbeveyh, Müberred, Zemahșerî, İbn Mâlik, Şâtıbî ve Ebû Hayyân'ın; usûle dair günümüze ulaşmış müstakil eserleri olmasa da bu bilginler, nahve ilișkin kaleme aldıkları eserlerinin satır aralarında serdettikleri bakıș açılarıyla söz konusu ilmin gelişmesine dolaylı katkı sağlayan Arap dili bilginleri olarak tarihteki yerlerini almışlardır. Çağdaş dönemde ise nahiv usulüne iliş̧kin çok sayıda eser telif edilmiștir. Bunların başlicaları olarak; Temmâm Hassan'ın "el-Usûl" ünü, Saîd el-Efğânî'nin "fì usûli'n-nahv" ini, Mahmut Ahmet Nahle'nin "Usûlü'n-nahvi'l-Arabî" sini ve Muhammed Hayr el-Hulvânînnin, "Usûlü'n-nahvi'lArabî" adlı kitaplarını sıralamak mümkündür. Adı geçen öncü Arap dili bilginlerinin nahiv metodolojisinde ele aldıkları ve tartıştıkları konuların en önemlilerinden biri, delillerin tearuzu ve tearuz eden deliller arasından hangisinin neye göre tercih edileceği hususu olmuștur. Zira Arap dili bilginleri; dil meselelerini çözümlerken ikna edici ve makul hükümlere ulaşmak için ciddi bir özveriyle çaba sarf etmiş olsalar da; kimi zaman aynı meselede ve düzlemde, sonucu doğrudan etkileyecek ve birbirinden farklı hükümlerin doğmasına yol açacak farklı delillerin çatışması hallerine de maruz kalmışlardır. Söz konusu durumlar karşısında çaresiz kalmayan dilciler; yetiştikleri ilmî çevre, tecrübe ve birikimlerinin de etkisiyle birtakım metodolojik çözümlere ulaşma başarısını gösterebilmişlerdir. $B u$ çözüm çabaları ise son tahlilde tercih yöntemi altında toplanmıstıtır. Böylece eserlerinde nakil, klyas, icmâ ve istishâb gibi delillerin kendi cinsleriyle veya birbirleriyle çelişme olgusu ve usul açısından hangisinin tercih edileceği hususu tartışmacı metodla ve örnekleriyle yer tutmuştur. Bu çalışmada söz konusu delillerin birbiriyle çatışma arz etmesi sorunu ve bu sorunun çözümünün keyfiyeti üzerinde durulacaktır. Şöyleki; giriș kısmında nahiv usulünün tarih sahnesine çıkış ve seyrine kısaca temas edilmiş, ardından makalenin ana temasını oluşturan tearuz ve tercih kavramlarının mahiyeti hakkında genel bilgiler verilmiş, daha sonra da asıl konuya geçilmiștir. Gelişme bölümünde nakil ile nakil, klyas ile klyas, nakil ile klyas, icma ile muhtelefûn fì ve istishâb ile diğer delillerin birbiriyle çatışma arz etmesi durumlarına ayrı başlıklar hâlinde ve bolca örnek eşliğinde yer verilmiștir. Böylece nakil ile naklin tearuzunda senet ve metin tenkidi, klyas ile klyasın tearuzunda delillerden birinin nakil veya klyas cinsinden eș değer bir bașka delille desteklenip desteklenmemiş olması hususu, tercih yöntemi olarak ön plana çıkan unsurlar olmuştur. Diğer çatışma hallerinde ise deliller hiyerarşisinin etkin rol oynadığı tespit edilmiştir.

Anahtar Kelimeler: Arap Dili ve Belagatı, Nahiv Usulü, Delil, Tearuz, Tercih.

\section{A Look at the Conflict Case of Primary Evidence and the Method of Preference in Nahiv Methodics}

\section{Summary}

The effort to create a functional methodology in any branch of science is a clear indication of the aim of reaching consistent and generally accepted concepts, theories and rules in that branch of science. The same effort and purpose has been witnessed in the Arabic language. The need to establish a functional methodology in order to reach the consistent and generally accepted language rules in Arabic linguistics must have made itself felt; In this respect, just as in the sciences of hadith and figh, the science of nahw was formed as a result of the careful efforts of Arabic language scholars such as Ibn Cinnî, Kemâleddin al-Enbari and Suyûtî. As a matter of fact, the fact that logical and procedural 
concepts, analyzes and approaches began to be seen intensively in Arabic linguistics with Ibn Jinni supports this situation. Again, Kemâleddîn el-Enbârî's underlining that he wrote his work upon the request of the scientific community in the preface of his work on the method named "el-ĭgrâb fí cedeli'l i'râb" stands before us as another strong data. Suyûtî, who has gifted works in many branches to the world of science, undertook the task of developing the science of nahiv method a little more and making it more compact, especially for his famous work titled "al-íktirah". Although Sîbeveyh, Müberred, Zemahșerî, İbn Malik, Şâtibî and Abu Hayyan on the grammar method; Although they do not have their own independent works on the method that have survived, these scholars have taken their place in history as Arabic language scholars who indirectly contributed to the development of the aforementioned science with the perspectives they put between the lines of their works on nahw. In the contemporary period, many works on the syntax method were copyrighted. As the main ones; Temmâm Hassan's "al-Usûl", Said el-Efghani's "fi usûli'n-nahv", Mahmut Ahmet Nahle's "Usûlü'nnahvi'l-Arabî" and Muhammed Hayr el-Hulvânî It is possible to list the books of "Usûlü'n-nahvi'lArabî". One of the most important issues that the aforementioned pioneering Arabic language scholars dealt with and discussed in the syntax methodology was the disagreement of the evidence and the issue of which one would be preferred among the contradicting evidences. Because the scholars of the Arabic language; although they have made a serious effort to arrive at convincing and reasonable judgments in resolving language issues; Sometimes, they were also exposed to conflicts of different evidences on the same issue and plane, which would directly affect the outcome and lead to different judgments. Linguists who are not helpless in the face of these situations; With the influence of the scientific environment they grew up in, their experience and knowledge, they were able to achieve some methodological solutions. These solution efforts are gathered under the preference method in the final analysis. Thus, in his works, the issue of which evidences such as narration, comparison, ijma and istishab conflict with their own kind or with each other and the issue of which one would be preferred in terms of procedure took place with argumentative method and examples. In this study, the problem of conflicting evidence with each other and the nature of the solution of this problem will be emphasized. as follows; In the introduction part, the emergence and progress of the syntax method on the stage of history was briefly touched on, then general information was given about the nature of the concepts of tearuz and preference, which constitute the main theme of the article, and then the main topic was given. In the development section, cases of conflict between transmission and transmission, qiyas and qiyas, ijma vs. mutalafun fih and istishab and other evidences are included under separate headings and accompanied by plenty of examples. Thus, the criticism of the promissory note and text in the conflict between the transfer and the transfer, and the issue of whether one of the evidences in the conflict of comparison and comparison is supported by another evidence in terms of transfer or comparison have come to the fore as a method of choice. It has been determined that the hierarchy of evidence plays an active role in other conflict situations.

Keywords: Arabic Language and Rhetoric, Nahiv Method, Evidence, Incompatibility, Preference.

\section{Giriş}

İnsanın doğasındaki öğrenme isteği ile meraktan kaynaklanan her şeyi sorgulama yetisi, yine insana ait olguların belki en başında yer alan dilde de tezahür etmiștir. Arap dilinin gramer safhasının oluşumunda da sorgulamaların etkisiyle engin bir deliller hiyerarşisi pay sahibi olmuştur. Dilin temel dinamikleri sayılan Kur'ân ve şiirin en başta yer aldığı deliller hiyerarşisinde, zihinsel eylemlerin neticesi sayılan icmâ, kıyas ve ıstıshâb gibi deliller de kendine esaslı bir yer edinmiştir. Böylece arka planda Arap dilinin gramerinin oluşumunda etkisi olan nahiv usulü ilmi teșekkül etmiştir.

Herhangi bir ilim dalına kendine özgü hüviyet kazandıran temel saikler kavram, kuram ve kurallar manzumesidir. Arap dilinde de durum farklı değildir. Özellikle İslami ilimlerde ve İslami ilimlerin araç dili olan Arapçada da kavram, kuram ve kuralların temelinde nakli ve akli deliller yer almaktadır. Bu delillerin kimi zaman aynı düzlemde ve yönde birbirini destekledikleri, kimi zaman da birbirine 
direnç gösterdikleri görülür. İşte delillerin birbirine aykırı olduğu bu durumda çözümlenmeye ihtiyaç duyan bir tearuz sorunu kendini göstermiş demektir. Fıkıh usulü bilginleri nezdinde hüküm istinbat eden müctehid nazarında iki delilin zahiren çatışma arz etmesi demek olan tearuz, nahiv usulünde; iki farklı aslın (delilin) aynı meselede ve aynı zamanda birbirinden farklı hükümleri gerektirmesi diye anlaşılmıştır. ${ }^{1}$ Nasıl ki usul bilginleri; ayet ile ayet, hadis ile hadis, ayet ile mütevatir hadis veya kıyas ile kıyas gibi aynı tür veya aynı düzeydeki deliller arasında zahiren beliren tearuzu gidermek için bir takım șartlar tayin ettilerse, nahiv usulü bilginleri de kendi uzmanlık alanlarında benzer eğilimi göstermişlerdir. Nitekim İbn Cinnî (ö. 392/1002) meșhur "el-Hasâis" adlı eserinde nahiv usulünün iki temel parametresi olan sema ile kıyasın çatışmasına dair müstakil bir bab açmış, yine kitabının satır aralarında delillerin tearuzu hâlinde dilciye yaraşan hususların boyutlarına yer yer değinmiștir. Kemâleddîn el-Enbârî (ö. 577/1181) de "Lumau'lEdille" de üç faslı bu konuya tahsis etmiş; ilkinde tearuzun anlamına, ikincisinde nakil ile naklin tearuzuna ve sonuncusunda da kıyas ile kıyasın tearuzuna dair kıymetli bilgiler vermiștir. Suyûtî (ö. 911/1505) ise bu iki eserdeki konuyla ilgili bilgileri "el-İktirâh" da bir araya getirdiği gibi, tearuz ve tercihe dair açtığı müstakil babda hem aslî delillerin tearuzuna, hem de ikinci derece sayılan bazı olguların birbiriyle çatıșması halleriyle ilgili olarak bir dizi bahse yer vermiștir. ${ }^{2}$ Delillerin tearuzu meselesinin çözümüne gelince fikıh usulcülerinin sırasıyla; nesih, tercih, cem' ve tevfîk ve tesâkut gibi yöntemleri ${ }^{3}$ kullandığı görülürken Arap dili bilginlerinin ise çözüm yöntemi olarak çoğunlukla tercihi benimsedikleri görülmektedir. Tercih; iki argümandan birinin mertebe açısından diğerinden üstün olduğunun ispatlanmasıdır. ${ }^{4}$

$\mathrm{Bu}$ araştırmada nahiv usulcülerinin eserlerinde ele aldıkları nakil, kıyas, icmâ ve istishâb gibi birincil delillerin kendi içlerinde ve birbirleriyle olan tearuz halleri ve bu tearuzu def etme yolu olarak da tercih yöntemi üzerinde durulacaktır. Yukarıda isimlerine kısaca değinilen nahiv usulü eserlerinde her ne kadar müstakil bir başlık altında birincil delillerin ${ }^{5}$ çatışma olgusu ele alınmış olsa da, örnekler sınırlı tutulmuştur. Klasik nahiv kaynaklarında ise benzer meselelerin çözümlerinde aynı metodolojinin uygulandığına dair yeterli ve ikna edici miktarda örnekleme rastlamak mümkün olsa da, bunlar satır aralarında dağınık şekilde yer almıştır.

1 Mahmud Ahmed Nahle, Usûlü'n-nahvi'l-Arabî (Beyrut: Dâru'l-Ulûmi'l-Arabiyye, 1. Basım, 1407/ 1987), 151.

${ }^{2}$ Nahle, Usûlü'n-nahvi'l-Arabî, 151.

${ }^{3}$ Muhammed Mustafa ez-Zühaylî, el-Vecîz fî usûli'l-fikhi'l-İslâmî (Dımeşk, Suriye: Dâru'l-Hayr li't-Tabâati ve'n-Neșri ve't-Tevzî', 1427/2006), 2/412-415.

${ }^{4}$ Ali b. Muhammed b. Ali ez-Zeynu'ş-Şerîf el-Cürcânî, Kitâbu't-Ta'rîfât (Beyrut: Dâru'l-Kutubi'l-Ilmiyye, 1. Basım, 1403/1983), 56.

5 Birincil delillerden kasıt; nakil, kıyas, icma ve ıstıshâb delilleridir. Nahiv bilginleri bazı gramer kurallarının tespitinde istihsan deliline de müracaat etmişlerdir. Ancak nahiv usulcüleri delillerin çatışması meselesinde istihsan delilini gündemlerine tașımamıșlardır. Diğer taraftan nahiv usulü bilginlerinden es-Suyûtî; zayıf lugat ile şaz lugat, asıl ile zahir, asıl ile galip, bir âlime nispet edilen iki kavil, kureyş lügati ile diğer lehçeler, mâni ile mukteza ve lafız ile mananın tearuzu gibi ikinci derece delil ve olguların da tearuzu üzerinde de durmuştur. Bu araștırmada söz konusu tearuz șekilleri kapsam alanı dıșında tutulmuştur. 
Yine ülkemizde; Ali Benli'nin “Ebû İshâk Eş-Şâtıbî̀de Nahiv Usûlü” ve Mehmet Şirin Çıkar'ın "Kıyas-Bir Nahiv Usul İlmi Kaynağı" adlı nahiv usulüne dair kıymetli çalışmaları, ana başlıkları ve ele aldıkları ana tema gereğince nahvin temel dinamiklerinin tearuzu olgusuna sinırlı düzeyde yer vermişlerdir. ${ }^{6} \mathrm{Bu}$ vesileyle bu araştırmada hem ele alınan meselelerin her biri örneklerle zenginleștirilmeye çalışılmış, hem de nahvî delillerin tearuzu olgusu doğrudan araştırmaya ana başlık kılınmak suretiyle konu biraz daha genişçe ele alınarak ülkemizdeki Arap dili alanındaki söz konusu boşluğun doldurulmasına nispeten katkı sağlamak amaçlanmıştır.

Öte yandan bu araştırma; nahvin temel dinamikleriyle ilgili usûlî esasları konu edinmiş olup, söz konusu esasları hangi dil bilgininin veya hangi ekolün dile dair içtihatlarına ne nispette yansıttığı meselelerine dair derinlikli araştırmaları başka çalışmalara bırakmıştır.

\section{Birincil Delillerin Tearuzu ve Tercih Yöntemi}

\subsection{Nakil ile Naklin Tearuzu}

Arap dili bilginlerinin doğrudan Arap dilini konuşanlardan aldıkları ${ }^{7}$ veya dile dair metinlerden muayyen șartlar dâhilinde aktardıkları dil malzemesini ${ }^{8}$ ifade eden nakil olgusu; Kur'ân-ı Kerîm, hadis-i şerîf ve Arap kelamından oluşmaktadır. ${ }^{9}$ Kemâleddîn el-Enbârî nakil olgusunu, "Sahih senetle nakledilmiş fasih Arap kelamı" olarak tarif etmiştir. ${ }^{10}$ Onun tarifine bakıldığında söz konusu muayyen şartların; fesahat, sahih senet ve Arap kelamı olduğu anlaşılmaktadır. Dilcilerin, kime ait olduğu bilinmeyen şiir veya nesirle istidlalde bulunmanın caiz olmadığına değinmelerinin sebebi olarak; fesahatine güvenilmeyen bir kimseden aktarılmış olması endişesini ve sahih senet şartının sağlanmamış olmasını göstermek mümkündür. ${ }^{11}$

6 Zira "Ebû İshâk Eş-Şâtıbî'de Nahiv Usûlü" adlı doktora tez çalışmasında; sadece nakil (sema) ve kıyas delillerinin kendi aralarında ve birbirleriyle çatışması hallerine başlıklar halinde değinilmiş, istishab ve icma delillerinin yer aldığı tearuz hallerine değinilmemiş ve adından da anlaşılacağı üzere konulara eş-Șatıbî’nin görüşleri çerçevesinde yer verilmiștir. [Bk. Ali Benli, “Ebû İshâk Eş-Şâtıbî'de Nahiv Usûlü" (İstanbul: Marmara Üniversitesi, Sosyal Bilimler Enstitüsü, Doktora tezi, 2013), 220 224.]. "Kıyas-Bir Nahiv Usul İlmi Kaynağı" isimli araştırmada ise söz konusu meseleye son derece sınırlı temas edilmiştir. [Bk. Mehmet Şirin Çıkar, "Klyas-Bir Nahiv Usul İlmi Kaynă̆ı" (Ankara: Akademisyen Kitabevi, 2. Basım, 2019), 163-167.]. Bunların yanı sıra Osman Güman'ın "Nahiv-Flkıh Usûlü İlişkisi (el-İsnevî Örneği)”doktora tez çalışması akla gelmekle birlikte, bu çalışmada yer yer fikhî delillerin çatışma hallerine yer verilmiş olup, nahvî delillerin tearuzu olgusuna müstakil bir başlık altında hiç yer verilmediği gibi bu meseleye neredeyse hiç değinilmemiştir.

${ }^{7}$ Ali Ebu'l-Mekârim, Usûlü't-tefkîri'n-nahvî (Mısır: Dâru Ğarîb Li't-Tabâati ve'n-Neşr-i ve't-Tevzî', 2007), 33.

8 Muhammed Han, Usûlü'n-nahvi'l-Arabî (Matbaatu Câmiati Muhammed Haydar, 2012), 28.

${ }^{9}$ Muhammed Han, Usûlü'n-nahvi'l-Arabî, 28.

10 Ebu'l-Berekât Abdurrahman b. Muhammed b. Ubeydullah el-Ensârî Kemâleddin b. Muhammed elEnbârî, el-ĭğrâb fî cedeli'l-i'râb, thk. Sa'id el-Efğanî (Dımeşk: Dâru'l-Fikr, ts.), 45.

${ }^{11}$ Bk. Abdurrahmân b. Ebî Bekr Celâleddîn es-Suyûtî, el-İktirâh fî usûlü'n-nahv (Dımeșk: Dâru'l-Beyrûtî, 2. Basım, 1407/2006), 59; Saîd el-Efğânî, Fî usûli'n-nahv (Beyrut: el-Mektebu'l-İslâmî 1407/1987), 65. Yeri gelmişken şu husus da belirtilmelidir ki; Kûfe ekölü söyleyeni bilinmeyen şiir veya nesirle istidlalde bulunmaları nedeniyle eleştirilmiştir. Örneğin; "كيا" dan sonra "أنيا" in gizlenmesinin vacip olmayıp aksine açığa çıkarılabileceği bağlamında Kufelilerin şiirden getirdikleri bir delil Enbârî 
Öte yandan Arap kelamı şartı, Arap olmayanları (müvelledûnu) tanımın dışına çı-

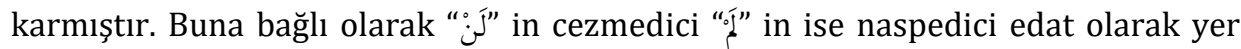
aldığı kelam, şaz kabul edilmiştir. Muvelledûn; cahiliye, muhadramûn ve mütekaddimîn (İslâmî dönem) şeklinde sıralanan ilk üç nesilden sonra dördüncü tabakayı ifade ettiği için bu tabakada yer alanların sözleri muteber kabul edilmemiștir. ${ }^{12}$

Nakil, nahiv kurallarının birçoğunun kendisiyle sabitliği sağlanmış olması nedeniyle ayrıcalıklı bir konumu haiz olmuş ve nahiv usulü delilleri sıralamasında her zaman zirvedeki yerini korumuştur. Bununla birlikte kimi zaman aynı meseledeki istidlâl aşamasında birbirine zıtlık arz eden iki naklin karşı karşıya kaldığı durumlar, nahiv bilginlerinin gündeminde yer almıștır. Böyle durumlarda nasıl bir yol takip edileceği bahsi ise nahiv usulünün kapsam alanına girmektedir. Nahiv metodolojisi açısından ele alındığında nakil ile naklin tearuzu; nakle dayanan bir asıl bir hükme delalet ederken, diğerinin o hükmün aksine delalet etmesi şeklinde anlaşılmıştır. ${ }^{13}$ Nahiv usulcülerinden Enbâri ve onu takip eden Suyûtî'nin kendi eserlerinde belirttiklerine göre; iki nakil arasında tearuz gerçekleştiğinde, ikisi de senet ve metin tenkidine tabi tutulmalı, tenkidin ölçütleri çerçevesinde de delillerden tercihe şayan olanı alınmalıdır.

Senetteki tercih ölçüsü; senetlerin birindeki ravi sayısının diğerinden sayıca daha fazla veya bilgi ve hafıza bakımından daha üstün olmasıdır. Kûfe ekolü mensubu Adî b. Zeyd el-İbâdî (ö. 600 civarı) şu şiir beytinden hareketle " "کَ" edatının “كَ" gibi nasb edebileceği çıkarımında bulunmuştur: (Basît)

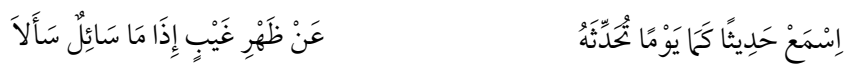

"Bir gün biri soru sorduğu zaman ezberden söyleyeceğin șu sözü dinle."

Ancak Basra ekolüne mensup Arap dili bilginleri; bu şiirdeki ilgili kelimenin mansûb olarak rivayetinin sadece Ravi Mufaddal ed-Dabbî (ö. 178/794) tarafından aktarılması şeklinde tek bir tarikten geldiğini; şiirin diğer râvilerinin şiirin

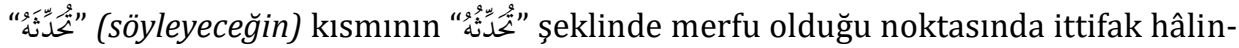

de olduklarını ve gerek Kûfe gerekse Basra ilim adamlarının bu noktada icmâ ettiklerini belirtmiştir. Buna göre kelimenin merfu olarak yer aldığı şiir tarikini rivayet eden raviler, diğer tarikin ravilerinden hem sayıca daha fazla hem de daha bilgili

tarafından, maksûr ismin şiir zarureti gereği medd edilebiceği noktasında şiirden getirdikleri bir delil de yine söyleyeni bilinmediği gerekçesiyle İbn Hișam tarafından kabul görmemiștir. (Bk. Ebu'lBerekât Abdurrahman b. Muhammed b. Ubeydullah el-Ensârî Kemâleddin b. Muhammed el-Enbârî, el-İnsâf fî mesâili'l-hilâf beyne'n-nahviyyîn el-basriyyîn ve'l-kûfiyyîn (Beyrut: el-Mektebetu'l-Asriyye, 1. Basım, 1424/2003), 2/475; Cemâlüddîn Ebû Muhammed Abdullah b. Yusuf İbn Hişâm, Evdahu'lmesâlik ilâ Elfiyyeti İbn Mâlik, thk. Yusuf eş-Şeyh Muhammed el-Bekâ'î (Dımeşk: Dâru'l-Fikr li'tTabâati ve'n-Neșr ve't-Tevzî', ts.), 1/13; Suyûtî, el-İktirâh, 59-61. ). Diğer taraftan modern nahiv usulcülerinden Saîd el-Efğânî (ö. 1997), Kûfe ekolünün sahibinden bașkasına atfedilen veya adalet ve zabt açısından açısından cerh edilmiş ravilerce rivayet edilmiş şiirlerle istidlalde bulunduğu noktasında da eleştiriler almış olduğunu aktarmıştır. (Bk. Efğânî, Fî usûli'n-nahv, s. 200 vd.)

12 Efğânî, Fî usûli'n-nahv, 64; Nahle, Usûlü'n-nahvi'l-Arabî, 31-32.

13 Menâhicu Câmiati'l- Medîneti'l-Âlemiyye, Usûlu'n-nahv (Câmiatu'l- Medîneti'l-Âlemiyye: ts.), 1/317. 
olmakla birlikte hafızaları da daha kuvvetli kabul edildiği için merfu olan şiir tariki diğerine tercih edilmiştir. ${ }^{14}$

Menkul kategoride yer alan kıraatten de senetteki tercih sebebine örnek göstermek mümkündür. Arap dilinde muzari fiilin şartın cevabında gelmesinin cevazı, başında "ف" edatının bulunmaması ve kendisinin de meczum olması şartlarına bağlıdır. İlgili edatın şartın cevabında yer alan muzarinin başına gelmesi için

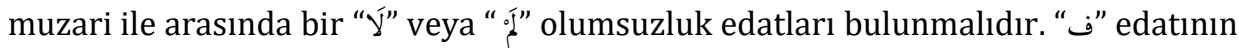
bu şartlar çerçevesinde muzarinin başına gelmesiyle artık muzari fiil mahzuf bir mübtedanın haberi konumunda olmuș ve kendisinin merfu olması da vacip hale gelmiştir. Araplar arasındaki yaygın kullanım da böyledir. Bu kaidenin delili olarak

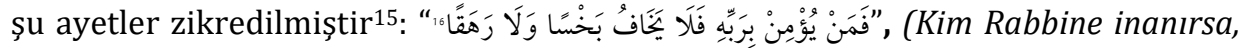
artık ne hakkının eksik verilmesinden, ne de haksızlığa uğramaktan korkar.) " وَمَنْ يَعْمَلْ مe مer kim mü'min olduğu halde sâlih amellerden işlerse artık o ne zulme uğramaktan ve ne de sevabının eksilmesinden korkar.) Meşhur kıraatlerde " "يَكَفاف" muzari fiili ayetlerde görüldüğü şekliyle merfu okunmuştur. Irak kıraati temsilcisi Yahyâ b. Vessâb (ö. 103/721) ise muzariyi meczum okumuştur. Bu kıraate göre, muzarinin başındaki " ${ }^{\prime}$ " edatı nâfiye değil nâhiye olarak düşünülmüştür. Ancak senedi yönüyle meşhur olan ilk kıraat şekline mukabil bu ikinci kıraat şaz sınıfında değerlendirilmiştir. ${ }^{18}$

Senetteki tercih sebebine kıraatten bir diğer örnek de şöyledir: Arap dilinde fiil cümlesindeki fiilin meçhul/edilgen kılınması halinde mefûlün bih unsurunun meçhul fiile nâib-i fâil olarak eşlik etmesi esastır. Diğer taraftan söz diziminde mefûlün bihin yer almaması halinde zarf, câr-mecrûr veya mastarın belli şartlar dâhilinde fâile niyabet edecek alternatif ögeler olabileceği kabul edilmiştir. Ancak; Kûfe ekolü ve Ahfeş (ö. 215/830) mefûlün bihe rağmen zarf, câr-mecrûr ve mastarın ister mefûlün bihten önce isterse sonra yer alsınlar nâib-i fâil olabileceklerini ileri sürmüşler ve bu noktada Ebû Ca'fer'in (ö. 130/747-48) "19 "يكِسِبْونَ نَ" [Herhangi bir topluma (kendi) kazandığının karşılığı verilsin diye...] kıraatine

14 Ebu'l-Berekât Abdurrahman b. Muhammed b. Ubeydullah el-Ensârî Kemâleddin b. Muhammed elEnbârî, Luma'u'l-edille, thk. Sa'id el-Efğanî (Dımeşk: Dâru'l-Fikr, ts.), 136-137; Suyûtî, el-İktirâh, 144145.

15 Ebû'l-Feth Osman el-Mavsılî İbn Cinnî, el-Luma' fi'l-Arabiyye, thk. Fâiz Fâris (Kuveyt: Dâru'l-Kutubi'sSekâfiyye, ts.), 135; Abbâs Hasan, en-Nahvu'l-vâfí (Kâhire: Dâru'l-Maârif, 15. Basım, ts.), 4/467.

16 Cin $72 / 13$.

17 Tâhâ 20/112.

18 Bk. Ebû Abdillâh el-Hüseyn b. Ahmed İbn Hâleveyh, Muhtasar fî șevâzzi'l-Kur'ân min Kitâbi'l-Bedî́ (Kâhire: ts.), 163; Ebû Muhammed Cemaleddin Abdullah b. Yusuf İbn Hişâm, Şerhu Şuzûri'z-zeheb fí ma'rifeti kelâmi'l-arab; thk. Muhammed Muhyiddîn Abdülhamid (Beyrut: el-Mektebetu'l-Asriyye, 1429/2008), 355.

19 Câsiye $45 / 12$. 
dayanmışlardır. Bu kıraate göre; ayetteki "بَّكَ" câr-mecrûru veya takdiren mevcut

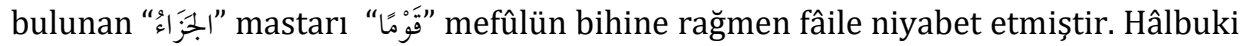

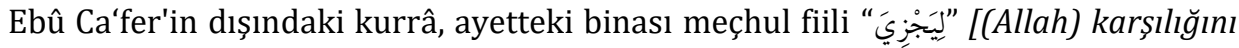
versin diye] şeklinde okumuşlardır. Ahfeş'in haricindeki Basra ekolü temsilcileri de ikinci kıraati hüccet kabul etmişlerdir. Ebû Ca'ferin kıraati ise diğer kıraate nispetle zayıf kaldığı için Arap dilbilimcilerince şâz kabul edilmiştir. ${ }^{20}$

Nahiv usulcüleri metindeki tercihin ölçüsünü ise, iki menkul delilden birinin kıyasa uygun diğerinin aykırı olması olarak tayin etmişlerdir. Bu hususta Şair Tarafe b. Abd'e (ö. 564) ait olan aşağıdaki beyitte yer alan "أَحْضرَ kelimesi Kûfe ve Basra ekolleri mensubu nahiv bilginleri arasında tartışma konusu olmuştur: (Tavîl)

$$
\text { أَلاََ أَهَهْنَا الزَّاجِرِي أَحْضُرَ الْوَغَى }
$$

"Dikkat! Ey benim savaşta bulunmama ve lezzetleri tatmama engel olan kişi, beni ölümsüz kılacak olan sen misin?"

Kûfe ekolüne mensup Arap dili bilginleri, sözde her hangi bir karşılı̆̆ı olmaksızın hazfedilmiş olan "أنْ" in amel edebileceği ictihadında bulunmuşlardır. Onlar görüşlerine bu beyti delil getirmişler ve beyitteki “"أَحْضُرَ" (bulunmam) kelimesinin mansûb okunduğuna dikkat çekmişlerdir. Basra ekolü mensubu nahiv bilginleri ise; kıyasa uygun olan merfu rivayetin kıyasa aykırı olan mansûb rivayete tercih edilmesinin evla olduğunu söylemişlerdir. ${ }^{21} \mathrm{Bu}$ bilginler mansûb rivayetin kıyasa aykırılığını ise, kelamda herhangi bir karine olmaksızın hazfedilen edatların gizlenmiş olarak amel edemeyecekleri şeklinde açıklamışlardır. Dolayısıyla meseleyi ikinci bir kıyas ameliyesiyle çözüme kavuşturmuşlardır. ${ }^{22}$

Arap dilinde cümlenin unsurlarının cümle içerisindeki dizilimi önem arz etmiştir. Özellikle fiil cümlesinde özel nedenlerin dışında fiil-fâil-mefûl şeklindeki sıralama ve bu temel ögelerin temyîz ve hal gibi yardımcı ögelere nispetle önce zikredilmesi hususu olduğu gibi gözetilmeye çalışılmıştır. Özel bazı durumlar ise dil âlimleri arasında tartışma konusu olmuştur. Onlardan biri de temyîzin kendi âmilinin önüne geçip geçemeyeceği meselesidir. Nahiv bilginleri temyîzin amilinin önüne geçip geçemeyeceği noktasında farklı fikirlere sahiptirler. Kûfe ekolü mensuplarının yanı sıra Ebû Osman el-Mâzinî (ö. 249/863) ve Müberred (ö. 286/900); temyîzin, çekimli âmilinin önüne geçebileceği düşüncesine sahipken, başta

${ }^{20}$ Ebû Bekr Muhammed b. es-Serî b. Sehl el-Bağdâdî İbnu's-Serrâc, el-Usûl fi'n-nahv, thk. Abdülhüseyin el-Fetilî (Beyrut: Muessesetu'r-Risâle, trs.), 1/80-81; Ebû'l-Bekâ Abdullah b. Hüseyin el-Ukberî, elLübâb fî ıleli'l-binâi ve'l-i'rab, thk. Abdülilâh en-Nebhân (Dımeşk: Dâru'l-Fikr, 1. Basım, 1416/1995), 1/159-160; Ebû Muhammed Cemaleddin Abdullah b. Yusuf İbn Hişâm, Şerhu Katru'n-nedâ ve bellu'ssadâ, thk. Muhammed Muhyiddîn Abdülhamid (Beyrut: el-Mektebetu'l-Asriyye, 1423/2003), 213214.

${ }^{21}$ Enbârî, Luma'u'l-edille, 137.

${ }^{22}$ Suyûtî, el-ïktirâh, 145. 
Sîbeveyh (ö. 180/796) olmak üzere Basra ekolüne mensup nahiv bilginleri buna cevaz vermemişlerdir. Birinci grup Mâzinî'nin söylediği şu şiir beytini delil getirmiştir: 23 (Tavîl)

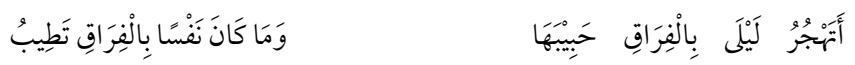

"Leylâ ayrllarak sevgilisini bıraklyor mu? (Ancak) can ayrılıktan hoşnut olmaz."

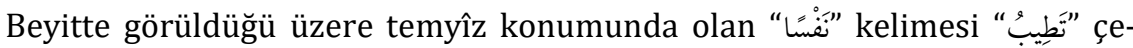
kimli fiilinin, yani amilin önüne geçmiştir. Buna mukabil Ebu İshak ez-Zeccâc (ö. 311/923), Ebu'l-Kâsım ez-Zeccacî (ö. 337/949) ve İsmail b. Nasr²4 ise yukarıdaki beytin ikinci şatrını "وَمَا كَانَ نَفْسي بِالْفِرَاقِ تَطِيبُ [(Ancak) ruhum ayrılıktan hoşnut olmaz.]

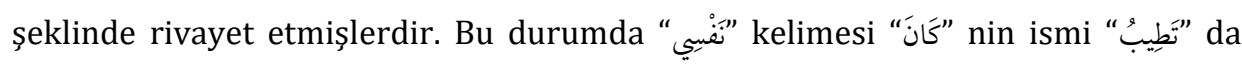
haberi olmaktadır. ${ }^{25}$ Cumhurun yer aldığı ikinci grup ise ikinci nakle itibar etmişlerdir. Böylece iki nakil karşı karşıya gelmiştir. İbn Cinnî söz konusu durumda kı-

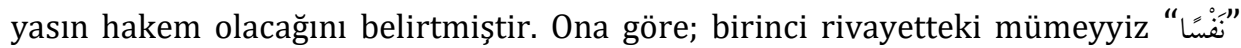
mana bakımından fâildir. Nasıl ki fâilin fiilin önüne geçmesi caiz değilse, aynı şekilde fâil manası taşıyan mümeyyizin de fiilin önüne geçmesi caiz değildir. İbn Cinnî bu kiyastan hareketle ref rivayetini nasb rivayetine tercih ederek ikinci grubun görüşünü desteklemiştir. ${ }^{26}$ Zaten Basra ekolü mensubu nahiv bilginlerinin kıyası

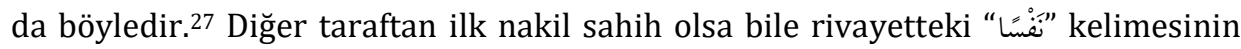
temyiz olmayıp aksine mukadder bir “" أَعْني (kasdediyorum) fiilinin mefûlü olarak mansûb olduğu şeklinde ikinci bir gerekçe de ileri sürülmüştür. ${ }^{28}$

Nahiv ilminde "إِّ" (haricinde) istisna edatından sonra munfasıl zamirin gelmesi mümkün ve caiz iken, doğrudan muttasıl zamirin gelmesi caiz görülme-

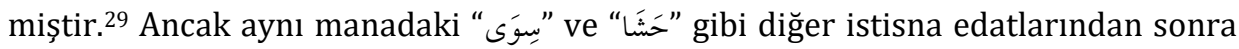

23 Ebu'l-Kâsım Mahmud b. Amr ez-Zemahșerî, el-Mufassal fî san'ati'l-i'râb, thk. Ali Bû Mulhim (Beyrut: Mektebetu'l-Hilâl, 1. Basım, 1993), 94; İbn Hişâm, Evdahu'l-mesâlik, 2/305.

24 Ölüm tarihi tespit edilememiştir.

25 Ebû'l-Bekâ Abdullah b. Hüseyin el-'Ukberî, et-Tebyîn 'an mezâhibi'n-nahviyyîn el-Basriyyîn ve'lKûfiyyîn, thk. Abdurrahman el- 'Useymîn (Beyrut: Dâru'l-Ğarbi'l-İslâmî, 1. Basım, 1406/1986), 396; Mecduddîn Ebu's-Saâdât el-Mubarek b. Muhammed İbnu'l-Esîr, el-Bedî' fì 'Ilmi'l-Arabiyye, thk. Fethî Ahmed Aliyyüddin (Mekke: Câmiatu Ummu'l-Kurâ, 1. Basım, 1420), 1/213; Menâhicu Câmiati'lMedîneti'l-Âlemiyye, Usûlu'n-nahv, 1/ 145 ve 2/234.

26 Bk. Ebû'l-Feth Osman el-Mavsılî İbn Cinnî, el-Hasâis (Kâhire: el-Hey'etu'l-Mısriyyetu'l-Âmme li'lKitâb, 4. Basım, ts.), 2/386.

27 Enbârî, el-İnsâf, 2/684.

28 Ebû'l-Hasan Muhammed b. Abdullah İbnu'l-Verrâk, 'İlelu'n-nahv, thk. Mahmud Câsim- Muhammed Derviş (Riyâd: Mektebetu'r-Rüşd, 1. Basım, 1420/1999), 393; Enbârî, el-İnsâf, 2/684; 'Ukberî, etTebyîn, 397.

${ }^{29}$ Ebu Muhammed Bedrettin Hasan b. Kasım b. Abdillah b. Ali el-Murâdî el-Mısrî el-Mâlikî, Tavdîhu'lmakâsıd ve'l-mesâlik bi şerhi elfiyeti İbn Mâlik, thk. Abdurrahman Ali Süleyman (Mısır: Dâru'l-Fikri'lArabî, 1. Basım, 1428/2008), 1/359. 
muttasıl zamirin gelmesinde ise bir beis yoktur. ${ }^{30}$ Bazı nahiv âlimleri aşağıdaki beyti şahit göstererek zaruret hâlinde "إلإ" istisna edatından sonra da muttasıl zamirin gelebileceğini ileri sürmüşlerdir: ${ }^{31}$ (Basît)

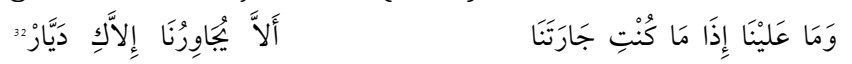

“(Ey sevgili) Sen bizim komşumuz olduğun zaman, başka birisi komşumuz olmamış ne çıkar!”

Beyit “吕” edatından sonra muttasıl zamirin şaz olarak gelebilirliğine delil olarak gösterilse de 33 ; Müberred (ö. 286/900) bu rivayetin aslının nahivcilerin di-

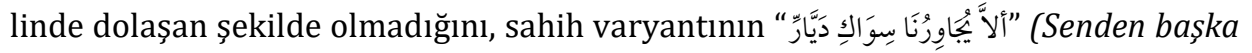
birisi komşumuz olmamış ne çıkar!) formunda olduğunu vurgulamıştır. Kimileri ise,

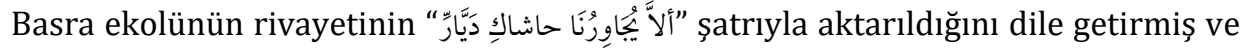
“吕” ibaresine medar olacak sağlıklı bir şahidin bulunmadığını göstermișlerdir. ${ }^{34}$ Buna göre birbiriyle çatışma teşkil eden bu iki rivayetten ilki şaz olup ikincisi kıyas delilince takviye edildiğinden ikinci rivayet tercih edilmiştir. ${ }^{35}$

Üzerinde kıyasî tahlilin yapıldığı nakillerin kıraatten bir örneği de şöyledir:

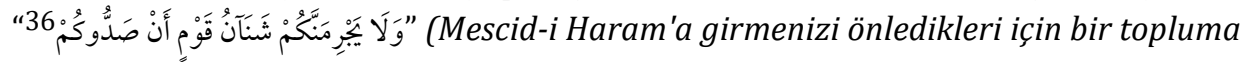
karşı beslediğiniz kin sizi tecavüze sevketmesin.) ibaresindeki “汇” edatının hemzesini Ebû Amr (ö. 154/771) ve İbn Kesîr (ö. 120/738) kesralı okurken, onların dışındaki kıraat âlimleri fethalı okumuşlardır. Ebû Ubeyd (ö. 224/838) de kesralı

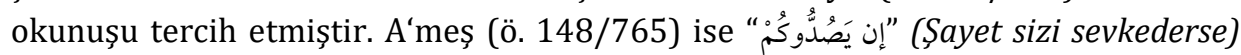
şeklinde hem kesralı hem de muzari fiille okumuştur. Ancak Nehhâs (ö. 338/950) kesralı okunuşun, nahivcilerin icmâıyla şiir zarureti dışında caiz olmadığını; İbn Cinnî ise bu tarz okunuşta zaaf bulunduğunu belirtmiştir. Zira kaideye göre; kesralı okunduğunda edat şart edatı vasfını haiz olmakta, şart edatı da bünyesinde meczum muzariyi barındıran bir cevap cümlesinin yanı sıra, bu cevap cümlesinin

30 Ebû Bişr Amr b. Osman b. Kanber Sîbeveyh, el-Kitâb, thk. Abdüsselâm Muhammed Hârun (Kahire: Mektebetu'l-Hancî, 1. Basım, 1408/1988), 2/350; Ebû Muhammed Cemaleddin Abdullah b. Yusuf İbn Hişâm, Muğni'l-lebîb an kutubi'l-e'ârîb, thk. Mâzini'l-Mubarek-Muhammed Ali Hamdullah (Dımeşk: Dâru'l-Fikr, 6. Basım, 1985), 732.

31 İbn Cinnî, el-Hasâis, 2/197; Ebû Abdullah Cemâlüddîn Muhammed b. Abdullah İbn Mâlik et-Tâî, Şerhu-teshîli'l-fevâid, nșr. Abdurrahman Seyyid - Muhammed Bedevî el-Mahtûn (Kahire: Hicrun li'tTabâati ve'n-Neşri ve't-Tevzi', 1. Basım, 1410/ 1990), 1/152.

32 Beytin sahibinin kim olduğu tam bilinmemekle birlikte bazı kaynaklarda beytin el-Ferrâ'ya ait olduğu aktarılmıştır. [Bk. Ali b. Mümin b. Muhammed Ebu'l-Hasen İbn 'Usfûr, Darairu'ş-şi'r, thk. es-Seyyid İbrahim Muhammed (Beyrut: Dâru'l-Endelus li't-Tabâati ve'n-Neşri ve't-Tevzi', 1980), 262.]

33 İbn Mâlik et-Tâî, Șerhu-teshîli'l-fevâid, 1/152.

34 Abdullah b. Abdurrahman el-'Ukaylî el-Hemedânî el-Mısrî İbn Akîl, Şerhu İbn Akîl 'alâ elfiyeti İbn Mâlik, thk. Muhammed Muhiddin Abdülhamid (el-Kâhire: Dâru't-Turâs, 20. Basım, 1400/1980), 1/90-91.

35 Temmâm Hassân, el-Usûl-dirâse ibistîmûlûjiyye li'l-fikri'l-luğavî ınde'l-arab en-nahvu - fikhu'l-luğa - elbelâga (Kâhire: Â'lemu'l-kutub, 1420/2000), 182.

36 Mâide 5/2. 
başında "ف" harfine ihtiyaç duymaktadır. Ayette söz konusu unsurlar yer almadığg için bu edat şart edatı değil, mastar harfi olabilir. Böylece " (sizi sevkettikleri için) terkibi cümle içerisinde mefûlün lieclih konumunda yer almıştır. ${ }^{37}$ Nehhâs, cumhurun kıraatinin geçerli olup diğer kıraatin geçersizliğine dair tarihi verilerden de kanitlar sunmuştur. ${ }^{38}$

Her ne kadar iki naklin çatışma arz etmesi hâlinde bunlardan birinin diğerine tercih edilmesinde kıstas olarak senet ve metin tahlili ön plana çıksa da, bu iki kıstasın yanı sıra nahiv âlimlerinin iki nakilden Araplar arasında daha meşhur olanına yöneldikleri de görülmektedir. Basra ve Kûfe ekollerini karşı karşıya getiren muhaffef "إِّ" in amel edip etmeyeceği meselesinin çözümüne katkı sağlayan şu nakil bunun örneğidir: (Hezec)

$$
\text { وصَذْرِ مُشْرِقِ النَّخرِ }
$$

Boğaz kısmını aydınlatan bir gögüs ki, sanki memeleri iki hokkadır.

Kaynaklarda kime ait olduğunun bilinmediği açıkça ifade edilen bu beyit, Sîbeveyh'in de etkisiyle Basra ekolünce muhaffef "إِن" in amel edişine kanıt olarak sunulmuştur. Kûfe ekolü ise zıt görüşe sahip olduğu için, beytin acüz kısmının " كَأَنْ " ثَدْيَاُه حُقَّانِ benimsemiştir. Bazı dilciler her ikisinin de caiz olduğunu belirtmişlerdir. ${ }^{40}$ Ancak Sîbeveyh ve Kemâleddîn el-Enbârî (ö. 577/1181) gibi dilciler, ilk rivayetin Araplar

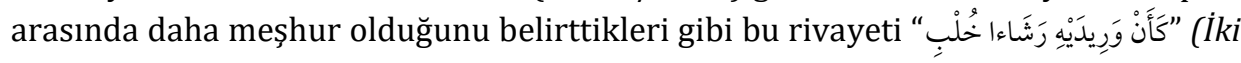
şahdamarı sanki liften ip gibidir.) formundaki bir başka delille de desteklemişlerdir. Ayrıca ikinci rivayetteki okuyuşa cevaz verilemeyeceğini, rivayet sahih olsa dahi "ثَدْيَاهُ حُقَّانِ ibaresinin mahzuf bir mübtedanın haberi olduğunu ve ifadenin orijinali-

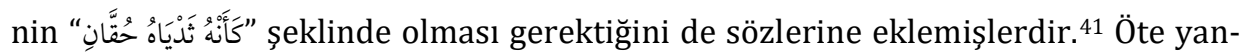
dan İbn Hişam da amelinin vacip olduğunu özellikle belirtmiştir. ${ }^{42}$

37 Ebû Câfer Ahmed b. Muhammed en-Nahvî en-Nehhâs, I'râbu'l-Kur'ân, hâșiye ve tâ'lik Abdulmunim Halil İbrahim (Beyrut: Dâru'l-Kutubi'l-Ilmiyye, 1. Basım, 1421), 1/256; Ebû'l-Feth Osman el-Mavsılî İbn Cinnî, el-Muhtesib fî tebyîni vucûhi șevâzzi'l-kıraâti ve'l-îdâhi anhâ (Mısır: Vizârâtu'l-Evkâf-elMeclisu'l-A'lâ li'ş-Şuûni'l-İslâmiyye, 1420/1999), 1/206.

38 Nehhâs; nahiv, hadis ve düşünce uzmanı birçok bilginin kesra ile kıraatten men ettiklerini belirtmiştir. 0 , ayetin Mekke'nin fethedildiği 8. hicri senede nazil olduğunu, müşriklerin hicretin 6 . senesinde müslümanları Hudeybiye'den men ettiklerini; dolayısıyla men olayının ayetin inişinden önce gerçekleşmesi ve kesra ile okuyuşun gelecek zaman manasını, fetha ile okuyuşun ise geçmiş zamanı manasını öne çıkarması nedenleriyle fetha ile okuyuşun doğrudan vacip olduğunu vurgulamıștır. (Bk. Nehhâs, I'râbu'l-Kur'ân, 1/ 256.)

39 İbn Akîl, Şerhu İbn Akîl 'alâ elfiyeti İbn Mâlik, 1/391; Abdurrahmân b. Ebî Bekr Celâleddîn es-Suyûtî, Hem'u'l-hevâmi' fì șerhi cem'ı'l-cevâmi', thk. Abdülhamit Hendâvî (Mısır: el-Mektebetu't-Tevfîkıyye, ts.), $1 / 561$.

40 Zemahşerî, el-Mufassal, 398; Ebû'l-Bekâ Yaîș b. Ali İbn Yaîș, Şerhu'l-mufassal li'z-Zemahşerî, thk. Emîl Bedi' Yakub (Beyrut: Dâru'l-Kutubi'l-Ilmiyye, 1. Basım, 1422/2001), 4/565-567.

41 Sîbeveyh, el-Kitâb, 2/136; Enbârî, el-İnsâf, 1/161-162.

42 İbn Hişâm, Şerhu Katru'n-nedâ, 176-177. 


\subsection{Kiyas ile Kiyasın Tearuzu}

Âlimlerin örfünde "Aslın hükmünün fer'e takdir edilmesi, bir illet münasebetiyle fer'in asla hamledilmesi veya her ikisini de kuşatan bir nedenle fer'in asla katılmasıdır."43 diye tanımlanan kıyası Kemâleddîn el-Enbârî (ö. 577/1181); "Ortak anlamı içerdikleri takdirde hakkında nakil gelmemiş meseleyi nakledilmiş olana hamletmektir." diye tanımlamıştır. Dolayısıyla kıyasın bir kaynak olarak varlığı ve fonksiyonelliği, naklin varlığına dayanmakta olup nakil ile kıyas arasında sıkı bir münasebet kurulmaktadır. Kemâleddîn el-Enbârî daha sonra her yerde fâilin merfû, mefûlun de mansûb olduğu hükümlerinin asıllarının kıyasî olduğunu vurgulamıştır. ${ }^{44}$ Nahiv usulü eserlerinde kıyasın illet, şebeh, tard, musâvî, evlâ ve edven gibi çeşitlerinden ${ }^{45}$ bahsedilmesine bakılırsa, onun nahiv usulü ilminde ne kadar yer ettiği ve nahiv bilginleri nezdinde diğer asıllara nispetle nasıl bir konuma sahip olduğu daha iyi anlaşlacaktır. Nitekim Kisâî (ö. 189/805) bir kasidesinde nahvin kıyastan ibaret olduğunu, Mâzinî Arap kelamına kıyas edilenin Arap kelâmından olduğunu, Kemâleddîn el-Enbârî de nahivde kıyasın inkârının mümkün olmadığını, nahvin tamamının kıyas olduğunu, kıyası inkâr edenin nahvi inkâr etmiş olduğunu belirtmişlerdir. ${ }^{46}$ Diğer taraftan Suyûtî, her ilmin bir kısmının nakil ve metinlerden, bir kısmının istinbat ve kıyastan ve bir kısmının da bir diğer ilimden alındığına değinerek kıyasın ilimlerdeki yeri ve önemine vurgu yapmıştır. ${ }^{47}$

Nahvin iki temel kaynağından biri olan kıyasa hem Basra ekolü hem de Kûfe ekolü yeri geldikçe başvurmuşlardır. Kendisine çokça müracaat edilişi, zihnî bir ameliye oluşu ve insana ait bir olgu oluşu gibi güçlü saikler bir araya gelince, zaman zaman aynı meselede iki zıt kıyasın karşı karşıya gelmesi kaçınılmaz olmuştur. Böyle durumlarda müşkülü gidermek için bilginler çözüm arayışı içine girmişlerdir. Nahiv usulüne göre; her biri ayrı birer hükmü ispatlayan iki kıyas delili birbiriyle çelişki arz ettiğinde aralarında tercihe uygun olanı alınır. Tercihteki ölçü, bu iki kıyastan birinin nakil ya da kıyas türünden başka bir delil tarafından takviye edilmiş olmasıdır. ${ }^{48}$

Nakil ile takviye edilmiş kıyasa şu örnek verilebilir: Kufe ekolü hicazî olarak bilinen "เم” edatının haberi naspetme gibi bir fonksiyonunun olamayacağını, haberin ancak "نَزْعُ خَافِضِ" (Harf-i cerin devre dışı bırakılması) yani mâ edatının haberinin başında yer alan harfi cerin mahzuf olmasıyla mansûb olacağını iddia etmişlerdir. Onlar bu hususta kıyas deliline dayanmışlardır. Kıyasa göre; bir edat ancak isim veya fiilden sadece birine has olursa amel edebilir. Tıpkı harfi cerlerin isimde, cezm edatlarının da fiilde âmil olması gibi. Eğer soru edatı olan "هََّ ve "و "atıf harfi

\footnotetext{
43 Enbârî, Luma'u'l-edille, 93.

${ }^{44}$ Enbârî, el-İğrâb fî cedeli'l-i'râb, 45.

45 Enbârî, Luma'u'l-edille, 105-106, 110; Nâdiye Ramazan en-Neccâr, el-Karâin beyne'l-luğaviyyîn ve'lusûliyyîn (Beyrut: Dâru'l-Kutubi'l-Ilmiyye, 1436/2015), 449.

46 Bk. Enbârî, Luma'u'l-edille, 95; Abbâs Hasan, en-Nahvu'l-vâfî, 3/190.

47 Suyûtî, el-İktirâh, 79.

48 Enbârî, Luma'u'l-edille, 138.
} 
gibi her ikisine de has olursa amelden yoksun olur. “" edat da " (Zeyd ayakta değildir.) ve "مَا يَقُومُ زَيْدُ (Zeyd ayağa kalkmıyor.) örneklerinde olduğu gibi hem isim hem de fiilin başına gelebilmektedir. Dolayısıyla isim ve fiil arasında müşterek olduğu için bu edatın amel etmemesi vaciptir. Bu nedenle Benû Temîm edatın amelini ihmâl etmişler, Hicazlılar ise amelini sağlamışlardır. Hicazlılar edatı mana itibariyle "لَيَس" ye benzetseler de, bu benzeyiş zayıf olup edatın lafiz cihetinden haberde amel etmesine varacak kadar güçlü değildir. Zira " لَّيَ" fiil, "ما" ise harftir. Harf fiilden zayıf olduğu için onun gibi amel etmesi batıldır. Dolayısıyla Kufe ekolüne göre burada haberin mansûb oluşu, başındaki "بِ" harfi cerinin mahzuf olmasıyla hâsıl olmuştur. Basra ekolü ise; “م”nın “" gibi amel etmesinin vacip olduğunu ileri sürmüştür. Onlara göre iki kelimenin birbirine benzerliği zayıf olmayıp, aksine birkaç yönden kuvvet kazanmaktadır. Her ikisinin de mübteda ile haberin başına gelmeleri ve hâli olumsuz kılmaları, her ikisinin de haberinin başına "ب " harfi cerinin gelmesi, yine her ikisinin de ğayrı munsarıf olmaları, aradaki benzerliği kuvvetli kılan etkenlerdir. Kıyasa göre, iki şey arasında en az iki cihetten benzerlik tespit edilirse hükümlerinin eşitliği de vücubiyet kazanır. Basralılar kıyas

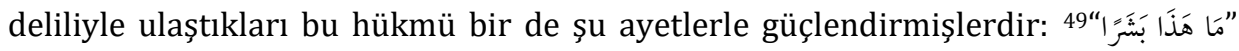

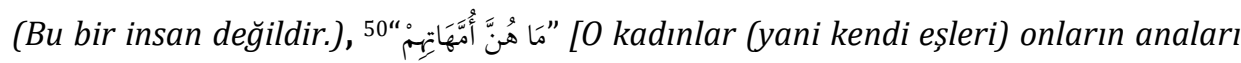
değildir]. ${ }^{51}$ Buna göre her iki ekol de kıyas deliline dayanarak iki ayrı hükme ulaşmış olsalar da, Basralılar'ın delili ayrıca nakil ile desteklendiği için ulaştıkları hüküm nahiv metodolojisiyle uyum arz etmektedir. Bu nedenle Kemâleddîn el-Enbârî de Basra ekolünün görüşünü tercih etmiştir. ${ }^{52}$

Arap dilbilimcileri ifadenin kapalılı̆̆a meydan vermeyecek derecede net olmasına kıymet vermişler ve anlaşllabilirliğin ihlaline yol açan etkenlerin izale edilmesi için de gereken özeni göstermişlerdir. Bu nedenle ifadenin karmaşıklığı ya da netliğini doğrudan belirleyecek etmenler üzerinde de kafa yormuşlardır. Söz gelimi anlatımın gayet net olduğu yerlerde gereksiz unsurların bulunmasına meydan vermemişler, anlatımın belirsizleştiği yerlerde de cümleye yardımcı unsurları ilave etmekten geri durmamışlardır. Bunun en açık örneklerinden biri de zamirle-

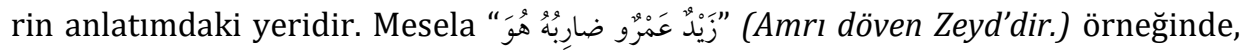
ism-i fâilden sonraki " "هو zamirinin aşikâr edilmemesi hâlinde ifadede ciddi bir kapalılık söz konusu olacağı için ilgili zamirin sözdeki yerini almasının vacip olduğu sonucuna vardıkları gibi bu noktada da ittifak etmişlerdir. ${ }^{53}$ Ancak " زَيْدُ هِنْدُ ضارِبهِ

\footnotetext{
49 Yûsuf 12/31.

50 Mücadele 58/2.

${ }^{51}$ Enbârî, el-İnsâf, 1/134-135.

52 Bk. Enbârî, el-İnsâf, 1/135.

${ }^{53}$ Bk. Enbârî, el-İnsâf, 1/50; İbn Akîl, Șerhu İbn Akîl 'alâ elfiyeti İbn Mâlik, 1/207-208; Ebû Muhammed Cemaleddin Abdullah b. Yusuf İbn Hişâm, Tahlîsu'ş-şevâhid ve telhisu'l-fevâid, thk. Abbas Mustafa es-
} 


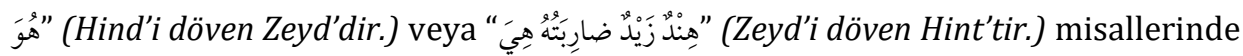
olduğu gibi ism-i fâilden sonraki "هو "هِيَّ" " vamirlerinin aşikâr edilip edilmemesi meramın kolaylıkla anlaşılmasını doğrudan etkilemediği durumlarda ise, zamirin açığa çıkarılması vacip midir değil midir noktasında ittifak edememişlerdir. Basra nahiv ekolü "lafzın anlam karmașasından halî olmadığı" kıyasına istinaden bu cümlelerdeki zamirlerin de açığa çıkarılmasının vacip olduğu hükmünü açıklarken, Kûfe ekolü tam aksine "lafzın anlam karmaşasından güvende olduğu" kıyasına istinaden cümlelerdeki zamirlerin aşikâr edilmesinin vacip değil, caiz olduğu hükmüne ulaşmışlardır. Ancak Kûfe ekolüne mensup Arap dili bilginleri kıyasen ulaştıkları söz konusu çıkarımlarına bir de nakilden delil getirmişlerdir: ${ }^{54}$ (Basît)

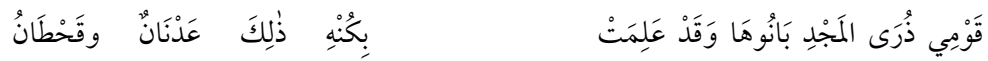

"Milletim şerefin en doruk noktalarını inşa etmiştir. Adnân ve Kahtân oğulları da vaziyetin iç yüzünü gayet iyi bilmişlerdir. "

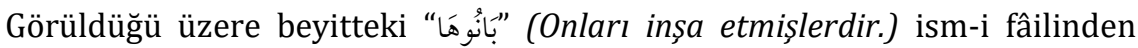
sonra ayrıca bir de "هُ" zamiri getirilmemiştir. Zamirin getirilmeyişi beyitte bir kapalılığa veya anlam karmaşasına da neden olmamıştır. Dolayısıyla bu nakille Kûfe ekolünün görüşü nahiv usulü açısından kuvvet kazanmış, İbn Mâlik (ö. 672/1274) de bu konuda Kûfe ekolünün görüşüne tabi olmuştur. ${ }^{55}$

Bazı Arap dili bilginleri arasında, "ليَ" nin ismi ile haberi arasına " nَّ" nın girmesi hâlinde amelinin bozulup bozulmayacağına dair ihtilaf hâsıl olmuştur. Ör-

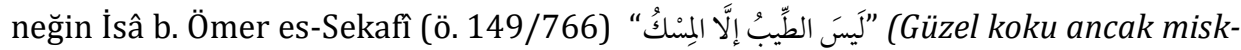
tir.) ifadesindeki "المِيٌْكُ" nın merfû telaffuzunun doğru olmadığl, mansûb telaffuz edilmesinin vacip olduğu görüşündedir. Zira ona göre kıyas bunu gerektirmiş olup Hicâzîler söz konusu kelimeyi mansûb telaffuz etmişlerdir. Ancak Ebû Amr b. 'Alâ (ö. 154/771) ise her iki okunuşun da caiz olduğu fikrine sahiptir. Ebû Amr, bu hükme hem kıyas hem de sema'dan esinlenerek ulaşmıştır. Zira Temîmîler " ليَسْ yi bu noktada “ما" ya benzeterek, nasıl ki “ما" nın araya gelmesiyle amelden mahrum oluyorsa, "لَيَسَ" yi de ona hamlederek aynı şart oluştuğunda onun da amelden düşeceğini benimsemişlerdir. Buna göre aynı şartlarda Temîmîler merfû okurken, Hicâzîler mansûb okamaktadırlar. Ebû Amr söz konusu durumu, İsâ b. Ömer ile aynı meclisi paylaştığı bir zaman diliminde öğrencilerinden birini Temîmîler'e, diğerini de Hicâzîler'e göndererek onlardan edindiği nakli delillerle ispatlamıştır. Bunun üzerine İsâ b. Ömer bu mevzudaki acziyetini kabul ederek kendi savunduğu fikirden vazgeçmiş ve her iki telaffuz şeklinin caiz olduğu diğer görüşü kabul et-

Salihî (Beyrut: Dâru'l-Kitâbi'l-Arabî, 1. Basım, 1406/1986), 186.

54 İbn Hişâm, Tahlîsu'ş-șevâhid, 186; Suyûtî, Hem'u'l-hevâmi', 1/367.

55 Suyûtî, Hem 'u'l-hevâmi', 1/367. 
mek durumunda kalmıştır. ${ }^{56}$

Kıyas ile desteklenmiş kıyasa ise şu örnek verilebilir: Kûfe nahiv ekolü “إنَّ" nin bir taraftan fiile benzerliği nedeniyle isminde nasb ile amel ettiğini, ama diğer taraftan fer'i olması hasebiyle mertebesinin amelde zayıf kaldığını ve haberi ref ${ }^{\prime}$ etmeye güç yetiremediği fikrini benimsemiştir. Böylece haber, “إِّ" edatı ismin başına gelmeden önce nasıl ki merfu ise yine öylece kalmıştır. Basra ekolüne göre ise bu görüş fasittir. Zira Arap dilinde bu durumun kıyas edilebileceği, başka bir kelime örneği yoktur. Onlara göre kıyas şunu gerektirir ki: “إنَّ” edatı nasıl ki ismini nasb ettiyse haberini de ref' etmiştir. Çünkü kendisi fiile benzediği için ismi,

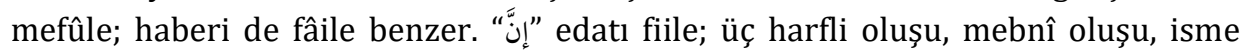
ihtiyaç duyuşu, sonuna "nûn-u vikâye" alışı ve "أَكَّْْتُ (Vurguladım.) fiilinin anlamını taşıması gibi açılardan benzerlik arz eder. Fiile benzerliği bunca açıdan kuvvet kazanmışken "İsmini naspedip haberini ref etmez." demek, kıyası terk edip anlamsız bir şekilde asıllara muhalefet etmek anlamına gelir ki, bu da caiz değildir. ${ }^{57}$ Vaziyete göre; ilk görüşü destekleyen bu tarzda ikinci bir kıyas örneği olmadığı için ikinci görüş tercih edilmiştir. 58

Arap dilbilimcileri cümlenin ögelerinin düzenli ve yaygın kullanım kurallarına uygun sıralanışını esas kabul etmişler ${ }^{59}$, düzensiz olsa bile fahiş hatayla göze çarpmaması kaydıyla kuruluşuna genişlik tanımışlar ve onu dahi belli kurallara bağlamaya çalıșmışlardır. Bu durumun bariz örneklerinden biri de olumsuzluk edatı olan "ما" nın haberinin mamulünün kendisinin önünde yer alıp alamayacağ meselesidir. Birçok konuda olduğu gibi bunda da iki meşhur nahiv ekolü ihtilaf etmişlerdir. Konuyla ilgili olarak Kûfe ekolü, “"طَََامَكَ ما زَيْدُ آكِلاً (Zeyd senin yemeğini yemiyor.) misalinde olduğu gibi “م” olumsuzluk edatının haberinin mamulünün "إَه، لَنْ، لاَ" kendisinin önüne geçebileceğini iddia etmiş, bu iddiasını ise onun tıpkı edatları gibi olumsuzluk edatı olduğu kıyasıyla perçinlemeye çalışmıştır. Basra ekolü ise Kûfe ekolünün bu iddiasına olumsuz yanıt vermiş ve kendi görüşünü yine

56 Bk. Sîbeveyh, el-Kitâb, 1/146-147; Ebû'l-Kâsım Abdurrahman b. İshak el-Bağdâdî ez-Zeccâcî, Mecâlisu'l-'ulemâ, thk. Abdusselam Muhammed Harun (Kahire: Mektebetu'l-Hancî, 2. Basım,1403/1983), 3-5; Ebû Abdullah Cemâlüddîn Muhammed b. Abdullah İbn Mâlik et-Tâî, Şerhu'lKâfiyeti'ş-Şâfiye, thk. Abdulmunim Ahmed Hureydî (Mekke: Câmiatu- Ümmu'l-Kurâ, 1. Basım, 1402/1982), 1/424-425; Ebû Hayyân Muhammed b. Yusuf el-Endelüsî, İrtişâfu'd-darab min lisâni'l'Arab, thk. Recep Osman Muhammed (Kahire: Mektebetu'l-Hancî, 1. Basım, 1418/1998), 3/1181; İbn Hişâm, Muğni'l-lebîb, 387-388.

57 Enbârî, Luma'u'l-edille, 139-140.

58 Temmâm Hassân, el-Usûl, 183.

${ }^{59}$ Cümledeki kurallı söz dizimi teorisi ve cümledeki gramatik yapının semantik boyutla ilişkisi üzerinde hassasiyetle durmuş ve özellikle bu yönüyle öne çıkmış Arap dili bilginlerinden birisi de Sa'duddîn et-Teftâzânî’dir (ö.792/1390). Sa`duddîn et-Teftâzânı̂’nin Arap dilinin genel yapısı çerçevesinde kurallı cümleyi tikelin tümelle olan içlem kaplam münasebeti dâhilinde ele alarak meseleye geniş bir perspektiften yaklaşması dikkate değerdir. (Bk. Duran Ekizer, "Sa`duddîn et-Teftâzânî̀nin (ö.792/1390) Şerhu Dîbâceti'l-Misbâh Adlı Risalesinin Tahkiki ve Nahiv Açısından Değerlendirilmesi", Ankara Üniversitesi İlahiyat Fakültesi Dergisi 62 (2021 ), 353-354. 
bir kıyasla destekleme yoluna gitmiştir. Onlara göre "ها", her ne kadar olumsuzluk vasfını tașıyorsa da kendisini önce bir ismin, sonra da fiilin takip ettiği bir edat olması yönüyle soru edatına benzemektedir. Soru edatının ise amel bakımından kendisinden sonraki kısmın kendisinden önceki kısım üzerinde hiçbir etkisi yoktur. Dolayısıyla "ما" için de aynı hüküm geçerlidir. Basra mektebi sadece bu kıyasla yetinmemiş, ayrıca ikinci bir kıyas ameliyesiyle daha içtihadını tahkim etme eğiliminde bulunmuştur. Şöyle ki; “" edatlarından sonra "مأَّ" da olduğu gibi isim değil, ancak fiil gelir. Böylece bu iki edat aslında fiilin bir cüzü gibidirler. "У” ya gelin-

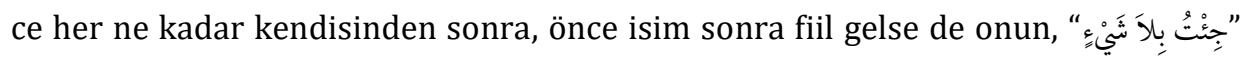
(Hiçbir şey getirmedim.) örneğinde olduğu üzere kendisinden önceki unsurun kendisinden sonraki unsurlar üzerinde amel etmesi gibi farklı bir özelliği daha vardır. $\mathrm{O}$ halde nasıl ki kendisinden önceki öge kendisinden sonrakini amel cihetinden etkileyebiliyorsa, bunun tersi de mümkündür. Böylece "م" edatının bütün bu edatlardan farkı ortaya konmuş olmaktadır. Görüldüğü üzere Basra ekolü, icra ettiği ilk kıyası ikinci bir kıyas ameliyesiyle daha besleyerek görüşünü desteklediği için bu konuda nahiv usulü açısından Kûfe ekolüne nispetle daha muteber bir içtihada sahip olmuştur. ${ }^{60}$

\subsection{Nakil ile Kıyasın Tearuzu}

Nahiv yöntembiliminde nahvin kaynakları arasında en mühimi ve rütbe bakımından en üstünü olarak "nakil" kabul edilmiştir. Zira nahivcilerin kıyasları Arap kelamına dayanmakta ve nahiv kuralları da onların sözlerinden istikra yöntemiyle elde edilmektedir. Bu nedenle Arap dili bilginlerinin hemen hepsi kıyas ile sahih naklin birbiriyle çelişki arz etmesi hâlinde naklin öncelenmesi ve tercih edilmesi yönünde hem fikirdirler. Nahiv bilginleri arasında Sîbeveyh her ne kadar Arapların sözüne dayanmayan kıyasın merdûd bir kıyas olduğunu söylese de ${ }^{61}$, kıyas ile naklin birbiriyle çatışması hâlinden ilk söz edenin Ebû Ali el-Fârisî (ö. 377/987) olduğu görülmektedir. Ebû Ali el-Fârisî; naklin kıyasın ulaştığı sonucun haricinde bir hükmü desteklemesi hâlinde kıyasın bir kenara bırakılıp naklin getirdiği hükmü esas edinmenin vacip olduğunu, aksi halde Arapların konuştuğu dilin dışına çıkılmış olunacağını, bu tutumun da kesinlikle yanlış olduğunu önemle vurgulamıştır. ${ }^{62}$ İbn Cinnî de naklin kıyasa öncelenmesi gereği noktasında hocası Ebû Ali'yi takip etmiş; bir kimsenin kıyasla bir çıkarımda bulunması, ardından Arapların bu çıkarıma karşıt bir şekilde konuştuğunu işitmesi hâlinde, o kişinin hemen kıyası terk edip Arapların sözüne yönelmesi gerektiğini söylemiştir. ${ }^{63}$ Ebû İshak eş-Şâtıbî (ö. 790/1388) ise, klyas ameliyesinden gayenin Arapların sahih kelamına ulaşmak

\footnotetext{
60 İbnu's-Serrâc, el-Usûl fi'n-nahv, 2/235; Enbârî, el-i̇nsâf, 1/140; Şâtıbî, el-Makâsıdu'ş-şâfiye, 2/164-168.

61 Sîbeveyh, el-Kitâb, 2/364-365.

${ }^{62}$ Ebû Ali el-Fârisî, el-Mesâilu'l-Halebiyyât, thk. Hasan Hendâvî (Dımeșk: Dâru'l-Kalem li't-Tabâati ve'nNeşr-i ve't-Tevzî', 1. Basım, 1407/1987), 226.

63 İbn Cinnî, el-Hasâis, 1/126.
} 
olduğuna, șayet onların kelamına sahih nakil yoluyla ulaşılmışsa kıyasın bir anlamının kalmayacağına vurgu yapmıştır. ${ }^{64}$ Nahiv bilginlerinin bütün bu usûlî yaklaşımları sanki fıkıh usulü bilginlerinin benzer mevzudaki bakış açılarına benzemektedir. Zira fikıh usulü bilginlerinin örfüne göre, fakih içtihat ettikten bir süre sonra içtihadının nassa aykırı olduğunun farkına varırsa içtihadından dönmesi ona vacip olur. 65

Nahiv usulünün öncü mimarlarından Kemâleddîn el-Enbârî (ö. 577/1181) nahvin delillerinin üç kısım olduğunu; bunların nakil, kıyas ve istıshâb olduğunu, delillerin mertebelerinin de bu sıralamaya göre olduğunu ve istidlâlde bu sıranın gözetilmesi gerektiğini sözlerine eklemiștir. ${ }^{66}$ Onu takip eden Suyûtî ise tüm icma ve kıyas çeşitlerinin nakilden bir dayanağının olması gerektiğini savunmuştur. ${ }^{67}$ Kemâleddîn el-Enbârî ayrıca kıyas ile istidlalde bulunmanın veto edilebileceği hususları yedi maddede toplamış, bunlardan birinin de "Bir meselede Araptan nakledilen sahih nassın zıddına olarak kıyas ile delil getirmek" anlamına gelen "fesâdu'litibâr" olduğunu söylemiștir. Kemâleddîn el-Enbârî bu yargısını örneklerle de desteklemiştir. Mesela; Basra mektebinin çoğunluğu ğayrı munsarıf isimlerin şiir zarureti çerçevesinde munsarıf kılınmalarının terkini kıyasen caiz görmemiştir. Zira isimlerin asıl hüviyeti onların munsarıf olmalarını gerektirir. Eğer ki, şiirlerde zaruret hâli gözetilmeksizin ğayrı munsarıf isimler oldukları hal üzere bırakılırlarsa aslın dışına çıkılmış olur. Bu fikrin aksini savunan Ahfeş, Ebû Ali el-Fârisî ve Kûfe ekolü ise, onların kıyas delilince ulaşmış oldukları bu çıkarımın Arap kelamına, yani naklî delile ters olduğunu düşünmüşlerdir. Söz konusu naklî delillerden bir tanesi sahabeden Hassan b. Sâbit'e (ö. 60/680) ait olan şu beyittir: (Kâmil)

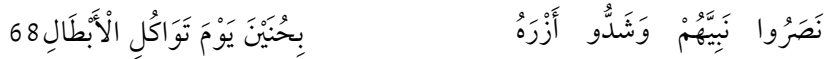

"Onlar; yiğitlerin birbirine güvenmediği Huneyn gününde, peygamberlerine arka çıkarak onun gücünü artırdılar.”

Beyitteki “حَحنَنِن kelimesi ğayrı munsarıf olup şiir zarureti gereğince munsarıf bırakılmamıştır. Kûfe ekolü sadece bu beyitle yetinmemiş, hepsinin burada anılamayacağı başka naklî delillerle de kendi içtihadını beslemiştir. Kemâleddîn elEnbârî Araplardan aktarılan nasslar karşısında yer alan Basra ekolünün bu kıyasını caiz görmemiş ve bu mevzuda Kûfe ekolünün görüşünü yerinde bulmuştur. ${ }^{69}$ Görüldüğü üzere bu duruma göre terazide nassın kefesi kıyasın kefesinden ağır basmakta ve sahih nas karşılığında kıyas ile istidlalde bulunmak caiz olmamaktadır.

Öte yandan İbn Cinnî Arap kelamının durumunu kıyasa nispetle dört açıdan

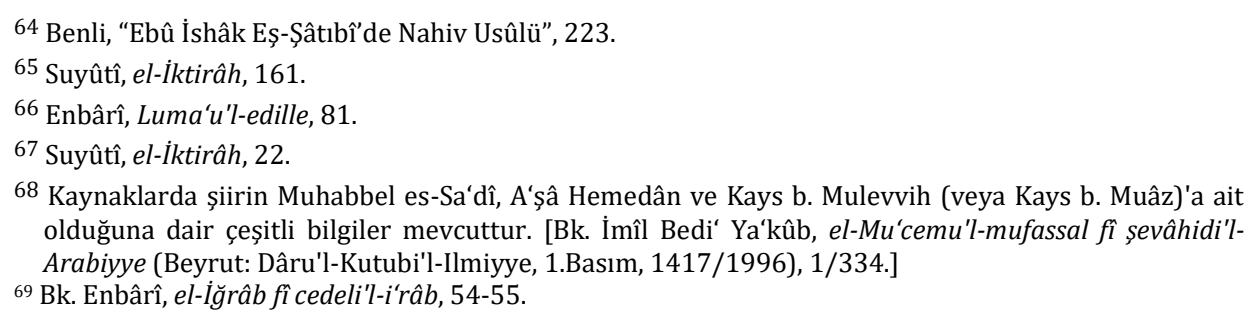




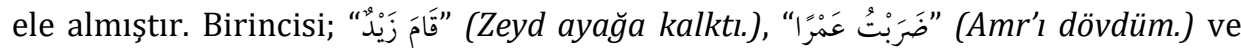
"مَرَزتُ بِسَعِيْدِد (Saîd'e uğradım.) örneklerinde olduğu gibi ref edici etkenlerle merfuluğun, nasb edici etkenlerle mansûbluğun ve cer edici etkenlerle mecrûrluğun sabit olduğu, yani hem muttarid (genel geçer) kıyas hem de muttarid naklin aynı hükümde örtüşmesi hâli ki, ona göre bu, usul açısından arzulanan bir durumdur. İkincisi; kıyasın muttarid, kullanımın şaz (sıra dışı) olması ve farklı hükümlere işaret etmeleri durumu ki, mesela "عَسَى" nın mefûlünün yani haberinin "عَسَى زَيْدُ قَائِكِاً (Belki Zeyd ayaktadır.) örneğinde olduğu gibi sarih (açık) isim olması, kıyasen muttarid olandır. Ancak sema sarih ismin terki üzere gelmiştir. Dildeki yaygın kullanım, "عَسَى زَيْدُ أَنْ يَقْوَمَ" (Zeyd'in ayağa kalkması umulur.) şeklinde olup Kur'ân-ı Kerim'de de aynı formda “فَسَسَى اللَّ أَنْ يَتْنِيَ بِالْفَتْحَ (Umulur ki Allah, bir fetih ihsan eder.) ibaresi yer almıştır. Kıyasen güçlü olan ilk örneğin Arap kelamında yeri olmadığı için kullanım bakımından şaz sayılmıştır. Bu nedenledir ki, Hicazîlerin kullandığı dil Temîmîlerin diline tercih edilmiştir. Zira Temîmîlerin dili kıyas cihetinden daha güçlü olmasına rağmen Hicazilerin dili kendisine daha yaygın bir kullanım alanı bulmuş ve bu nedenle de Kur'ân-ı Kerîm Hicazîlerin diliyle nazil olmuştur. ${ }^{71}$ Üçüncüsü de; kullanımın muttarid kıyasın şazz olduğu durumdur. Örneğin; ilâl kaidesine göre, bir kelimede "و" veya "ي" harekeli ve kendilerinden önceki harf fethalı olduğunda bu harfler elife dönüşür. Ancak Kur'ân-ı Kerîm'de yer alan "

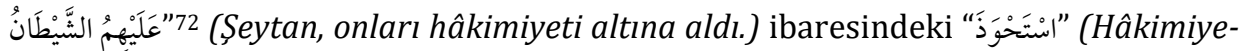

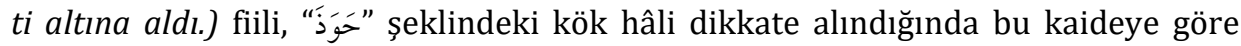
"اسنَحَاذَ" şeklinde olması gerekirken öyle gelmemiştir. İbn Cinnî usulî bir yaklaşımla; böyle durumlarda semanın olduğu hal üzere alınıp öylece kabul edilmesi gerektiğini, ancak "إِانْتَبَعَ" (Dik durdu.) ve" (Satın almayı istedi.) gibi aynı kalıtaki

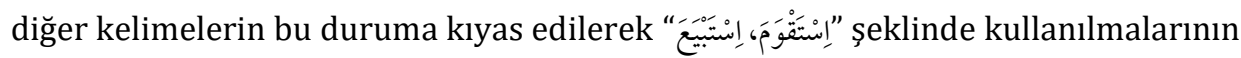
caiz olmadığını söylemiştir. Zira ona göre, kıyasa aykırı olarak gelen sema olduğu şekliyle alınıp kullanılır, ama başka bir mesele ona asla kıyas edilmez. Dördüncü ve

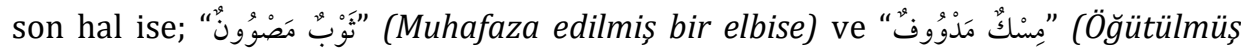
misk) misallerinde olduğu gibi, sakin vavdan önce dammeli vavın okunduğu hem kıyasen hem de kullanım açısından şaz olan hal ki, bunlara ne kıyas yapılır, ne de kullanımı doğru ve hoștur. Bu son hâlin kullanımı sadece hikâye türünde geçerli kabul edilmiştir. ${ }^{73}$

70 el-Mâide 4/52.

71 İbn Cinnî, el-Hasâis, 1/126; Nahle, Usûlü'n-nahvi'l-Arabî, 153.

72 Mücâdele 58/19.

73 İbn Cinnî, el-Hasâis, 1/98-100; Abdurrahmân b. Ebî Bekr Celâleddîn es-Suyûtî, el-Muzhir fí ulûmi'lluğati ve envâihâ, nșr. Fuâd Ali Mansûr (Beyrut: Dâru'l-Kutubi'l-Ilmiyye, 1. Basım, 1418/1998), $1 / 181$. 
Kıyas ile naklin karşılaştığı düzlemde bazen kıraatler de Arap dili bilginleri arasında tartışma konusu olmuştur. Dil bilginleri istikra ve kıyas metoduyla ulaştıkları ve doğruluğuna kesin olarak inandıkları kimi kaidelerin itibarını ve varlığını korumaya çalışmışlar, bazen nakil yoluyla gelen verilerin ulaştıkları bu kaidelere uygunluğunu test etmekten kendilerini alamamışlar ve neticede bazı mütevatir kıraatleri dahi eleştirmekten geri durmamışlardır. Muzâf ile muzâfun ileyhin arasının bir başka ögeyle ayrışıp ayrışmayacağı meselesi bunlardan biridir. Bu meselede Kûfe ekolü, şiir zarureti kapsamında muzâf ile muzâfun ileyhin arasının zarf veya câr-ı mecrûr dışındaki bir başka unsurla ayrılabileceği kanaatini savunmuş, Basra ekolü ise iki unsurun arasının ancak zarf veya câr-ı mecrûr kategorisindeki kelime türleriyle ayrışabileceği noktasında karşı tezini ortaya koymuştur. Kûfe ekolünün kendi tezinde ileri sürdüğü argümanlardan biri, “74 وَكَذَلِكَ زَيَّنَ لِكَثِيْرِ مِنَ المُشْرِ كِينَ "قَتَلْ أَوْلادِهِمْ شُرَكَاؤهُْْ [Böylece ortakları, müşriklerden çoğuna çocuklarını (kızlarını)

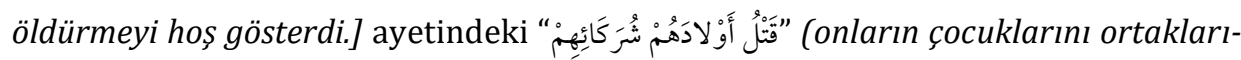
nın öldürmesini) şeklindeki İbn Âmir (ö. 118/736) mütevatir kıraatidir. Bu kıraate göre "أوْلادَهْمْم" (onların çocuklarını) kelimesi zarf ve câr-ı mecrûr dışındaki bir kelime türü olarak görüldüğü üzere muzâf ile muzâfun ileyh arasına girmiştir. Ancak Basra ekolü muzâf ile muzâfun ileyhin, araları ayrılamaz bir bütün olduğunu, bu münasebetle kıyasen vardıkları kararla İbn Âmir kıraatinin zayıf olduğunu, eğer geçerli olsaydı Arapların en fasih kavli olması gerektiğini savunmak durumunda kalmışlardır. ${ }^{75}$ Basra ekolünün bu tezine Ferrâ (ö. 207/822), Sîrâfî (ö. 368/979), İbn Cinnî ve Zemahșerî (ö. 538/1144) gibi bazı Arap dili bilginleri de destek vermişlerdir. Ferrâ, bu tarzın benzerini Arap dilinde görmediğine, İbn Cinnî geçerliliğinin zor olduğuna, Sîrâfî bu kıraati benimseyenlerin yanıldıklarına ve Zemahșerî şiirde zarureten dahi bulunması hoş olmazken fesahat ve belagatiyle mucizevî bir kitap olan Kur'ân'da bulunmasının imkânsızlığına vurgu yapmışlardır. ${ }^{76}$ Ancak kıyasın yanında yer alan bu dilcilerin tezini çürütme yoluna giden nahiv bilginleri de yok değildir. Özellikle meşhur nahiv bilgini İbn Mâlik (ö. 672/1274), nasıl ki söyleyeni ya da ravisi bilinmeyen bir şiirle dahi dil kurallarının ispatına cevaz veriliyorsa, Kur'ân kıraatiyle dil kaidelerinin tahkim edilmesinin daha evlâ olduğunu söyleyerek bu mevzuda İbn Âmir kıraatinin yanında yer aldığını açıkça göstermiştir. Ebû Hayyân da söz konusu kıraatin caiz olduğunu ve benzerinin Arap şiirlerinde de mevcut olduğunu anlatarak İbn Mâlik'i desteklemiştir. Suyûtî ise usulen Kur'ân kıraatlerinin hepsinin hüccet olduğunu beyan etmiş ve bu kıraate de yer vermiștir. ${ }^{77}$ Görüldüğü üzere bazı Arap dili bilginleri teoride usulen benimsedikleri

74 Enâm 6/137.

75 Enbârî, el-İnsâf, 2/352 ve 355.

76 Bk. Ebû Zekeriyya Yahya b. Ziyâd b. Abdillah b. Manzûr ed-Deylemî el-Ferrâ, Me'âni'l-Kur'ân, thk. Ahmet Yusuf en-Necati ve diğerleri (Mısır: Dâru'l-Mısriyye li't-te'lif ve't-Terceme, 1. Basım, ts.), 1/358; Ebû Sa'îd el-Hasen İbni Abdillah es-Sîrâfî, Şerhu Kitabi Sîbeveyh, thk. Ahmed Hasan Mehdelî ve Ali Seyyid Ali (Beyrut: Dâru'l-Kutubi'l-Ilmiyye, 1. Basım, 2008), 1/242; İbn Cinnî, el-Hasâis, 2/409; Ebu'l-Kâsım Mahmud b. Amr ez-Zemahșerî, el-Keșşâf an hakâikı ğavâmidı't-tenzîl (Beyrut: Dâru'lKitâbi'l-Arabî, 3. Basım, 1407), 2/70.

77 Bk. İbn Mâlik, Şerhu'l-Kâfiyeti'ş-Şâfiye, 1/87; Ebû Hayyân el-Endelüsî, İrtişâfu'd-darab, 4/1846; 
önemli kaidelere uygulamada zaman zaman kendileri de aykırı davranmışlardır. ${ }^{78}$

Modern dönem usulcülerinden Mahmut Ahmet Nahle; bir kuralın hükmünün kıyasen vacip, zıddının ise semaen caiz olması hâlinde, bu hususu açıklığa kavuşturan bir başka delil bulununcaya kadar kıyasın alınmasının esas olduğunu belirtse de, bu duruma herhangi bir örnek göstermemiştir. ${ }^{79}$

Özetle; gramer kurallarının belirlenmesi yönteminde, bir diğer ifadeyle nahiv usulünde, naklin diğer delillere nispetle birincil bir konuma sahip olduğu noktasında Arap dilbilimcileri nezdinde teorik manada icma hâsıl olmuştur.

\section{4. İcmâ Edilmiş Bir Konu İle İhtilaflı Konunun Tearuzu}

Nahiv yöntembiliminde "icmâ" denilince, Basra ve Kufe nahiv ekollerinin her hangi bir dil meselesinin çözümü üzerinde fikir birliğine varmış olmaları anlaşılmıştır. ${ }^{80}$ İcmanın Arap dilbilimcileri nezdinde önemli bir yeri olduğu görülmektedir. İlk olarak Sîbeveyh kendinden önceki nahiv âlimlerin ittifak ettikleri hususları veya Arapların icmasını kendi nahiv usulünde delil olarak kullanmış, Müberred ondan daha belirgin bir şekilde bu delile tutunmuştur. ${ }^{81}$ Hatta Müberred nahiv bilginlerinin icmasının ona karşı çıkanlara karşı bir hüccet olduğunu net bir şekilde ifade etmiştir. ${ }^{82}$ Ferrâ, icmayı hilafına gidilmemesi gereken bir asıl olarak görmüştür. Nitekim o, yer yer kıraat bilginlerinin üzerinde icma ettiği kıraat șekillerine değinmiş ${ }^{83}$, icmaya aykırı olan kıraat tarzını da hoş karşılamamıştır. ${ }^{84}$ İbn Cinnî de, icmayı nahiv usulü delilleri arasında saymıștır. Ancak ona göre, icmanın delil oluşu nahvin iki ana kaynağı olan sema ve kıyasa aykırı olmaması şartına bağlıdır. ${ }^{85}$ Aynı şekilde sonraki dönem nahiv âlimleri de icmayı muteber asıllardan kabul etmişler, icmaya muhalefetin caiz olmadığını belirtmişlerdir. Örneğin Haşşâb (ö. 567/1172) öncekilerin icmasına muhalefetin geçerli olmadığını, Ukberî (ö. 616/1219) de icmaya aykırı olanın reddedilmiş olduğunu söylemiştir. ${ }^{86}$ Ebû İshak eş-Şâtıbî'ye (ö. 790/1388) göre de nahiv bilginlerinin icmâına muhalefet; fakihler, usulcüler ve muhaddislerin icmâına muhalefet gibi olup hangi ilmin erbabı bir mesele üzerinde ittifak ettiyse onların icmâı hüccettir ve onlara muhalefet eden de hata etmiş

Suyûtî, el-iktirâh, 38-39.

78 Bunun en açık örneği İbn Cinnî'dir. Şöyle ki; özellikle İbn Cinnî'nin İbn Âmir kıraatine ilişkin buradaki fikri, gerek nakil-kıyas çatışmasıyla ilgili olarak usul açısından yukarıda geçen genel ve kesin tavrıyla ve gerekse yine kıyasa aykırı olduğu halde "اسنتَحْوَذَعَلَيْهِمُ الشَّيَْْانُ ayetiyle ilgili tutumuyla çeliş̧i arz etmektedir.

${ }^{79}$ Nahle, Usûlü'n-nahvi'l-Arabî, 153.

${ }^{80}$ Suyûtî, el-iktirâh, 73.

${ }^{81}$ Muhammed Hayr el-Hulvânî, Usûlü'n-nahvi'l-Arabî (Rabat: en-Nâşir el-Atlasî, 1983), 127.

82 Ebu'l-Abbâs Muhammed b. Yezîd el-Muberred, el-Muktedab, thk. Muhammed Abdulhâlik Azîme (Beyrut: Âlemu'l-Kutub, ts.), 2/175.

${ }^{83}$ Ferrâ, Me'âni'l-Kur'ân, 3/184.

${ }^{84}$ Ferrâ, Me'âni'l-Kur'ân, 3/358.

85 İbn Cinnî, el-Hasâis, 1/190-191.

${ }^{86}$ Hulvânî, Usûlü'n-nahvi'l-Arabî, 128. 
olur. ${ }^{87}$ Yine Şâtıbî nahiv bilginlerinin hükmü üzerinde uzlaștığı hususlarda onlara itiraz edenlerin görüşlerine ehemmiyet vermemiştir. ${ }^{88}$

Basra ve Kûfe ekolleri birçok nahvî meselede ihtilafa düştülerse de, ittifak ettikleri meşhur nahiv konuları vardır. "اسم" kelimesinin başındaki hemzenin tavîz/ivaz hemzesi olduğu, beş ismin müfret hallerinin harekeyle irab edildiği, mübteda ve haberi ref eden aslî unsurların ne olduğu, haberin mübtedaya

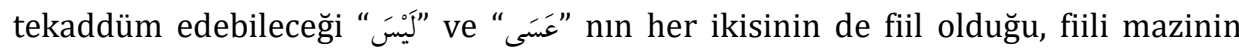
hazfedilmiş bir mevsufun sıfatı olduğunda hal konumunda gelebileceği, zarf veya câr-ı mecrûrdan sonra gelen ismi bunların ref etmeyeceği, "مَا دَامَ (diğı sürece) nin haberinin kendisinin önüne geçemeyeceği, mecrûr zamirin mecrûr olan zahir isme atfedilemeyeceği, muzari fiilin isme benzediği için mureb olduğu gibi birçok hükmü bu iki ekolün üzerinde görüş birliğine vardığı hususlar olarak sıralamak mümkündür. ${ }^{89}$

Nahiv metodolojisinde, dilcilerin hükmü üzerinde uzlaşma sağladığı bir konu ile uzlaşma sağlayamadığı bir konu birbiriyle çatışırsa ilkiyle istidlâlde bulunmak bir yöntem olarak tayin edilmiștir. Örneğin, şiir zarureti meyanında memdûd ismin kasredilmesi (kısaltılması) hem Basra hem de Kûfe ekollerince caizdir. Ancak tersi, yani maksûr ismin yine şiir zarureti meyanında uzatılmasına Kûfe ekolü cevaz verirken Basra ekolü karşı görüş beyan etmiştir. ${ }^{90}$ Basra ekolüne mensup nahiv bilginlerine göre, memdûd isimlerin elifi her zaman zâid olurken maksûr isimlerin elifi aslından da olabilir. Böylece memdûd isim kasredildiğinde aslına dönmüş olduğu için caiz, diğerinde ise kelimenin aslının bozulma ihtimali olduğu için caiz değildir. ${ }^{91} \mathrm{Bu}$ nedenle bu ikinci meselede icma oluşmamıştır. Dolayısıyla iki husus aynı düzlemde çatıştığında üzerinde icmânın sağlandığı ilk görüşe göre hareket etmek nahiv usulünün gereğidir. ${ }^{92}$

Basra ve Kûfe ekollerine mensup nahiv bilginleri "زيَيْد قَائهُ " (Zeyd ayaktadır.) ve "عَمْنُو حَسَنْ (Amr iyidir.) cümlelerinde olduğu gibi haberin ism-i fâil veya sıfat-1 müşebbehe gibi sıfat grubunda yer alan bir kelime olması hâlinde, mübtedaya dönen bir zamiri içerebileceğinde icma etmişlerdir. Zira sıfatlar hem lafız hem de

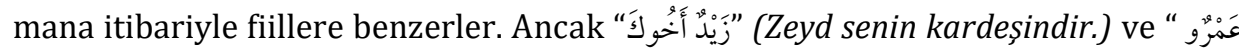

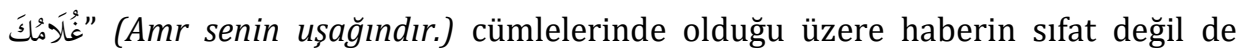
camid isim olması durumunda, haberde mübtedaya dönen bir zamirin olup olama-

${ }^{87}$ Ebû İshak İbrahim b. Musa eş-Şâtıbî, el-Makâsıdu'ş-şâfiye fî șerhi hulâsati'l-Kâfiye, thk. Abdurrahman b. Süleyman el-Useymi ve diğerleri (Mekke: Câmiatu Ummi'l-Kurâ, 1428/2007), 2/71. akt. Benli, "Ebû İshâk Eş-Şâtıbî'de Nahiv Usûlü", s. 221.

88 Benli, "Ebû İshâk Eş-Şâtıbî'de Nahiv Usûlü”, s. 222.

${ }^{89}$ Nahle, Usûlü'n-nahvi'l-Arabî, 81-85.

90 Suyûtî, el-İktirâh, 151.

91 Enbârî, el-İnsâf, 2/617.

92 Suyûtî, el-İktirâh, 151. 
yacağı noktasında iki ekol ihtilaf etmiştir. Kûfe ekolü “" أَخْ “

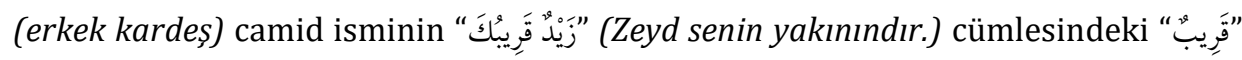
sıfatı tevilinde olduğunu, dolayısıyla bu cümledeki “乌َ” zamiri gibi mübtedaya dönen bir muttasıl zamire bitişebileceğini ifade ederken Basra mezhebi; camid ismin salt isim olduğunu, hem lafzen hem manen ne sıfata ne de fiile benzediğini, bu nedenle mübtedâya dönen bir zamire bitişmesinin mümkün olmadığını belirtmişlerdir. ${ }^{93}$ Üzerinde ittifakın hâsıl olduğu birinci mesele ${ }^{94}$ ile ihtilafın gerçekleştiği ikinci mesele ${ }^{95}$ aynı konuda karşı karşıya geldiği için, nahiv usulü açısından ikincisine itibar edilmemelidir.

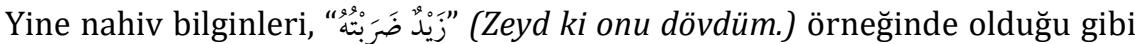
haberde mübtedaya dönen bir zamirin olması hâlinde haberin mübtedaya tekaddüm edebileceği konusunda ittifak etmişlerdir. Ancak "الزََّّْدَانِ قَامَا" (İki Zeyd ayağa kalktılar.) da durum aynı değildir. Ahfeş ve Müberred ilk meseleye kıyasla tekaddüme cevaz vermişken, onların dışındaki Basra mezhebi mensupları haberdeki elifin zamir değil müsennâlık alameti olduğu gerekçesiyle aynı kanaatte olmamışlardır. ${ }^{96} \mathrm{Bu}$ nedenle usul açısından yine icmanın hâsıl olduğu ilk meselenin hükmü diğerine nispetle evlâdır. Şâtıbî'ye göre de, bir kimse "قََمَا الزَّيْدَانِ" cümlesinin caiz olmamasına kıyasla "زَيْدُ ضَرَبْهُهُ cümlesinin de caiz olmadığını söyleyip icmaya muhalefet edecek olursa bu itiraz kabul edilemez. ${ }^{97}$

\section{5. İstıshâb Delilinin Nakil veya Kıyas ile Tearuzu}

Kemâleddîn el-Enbârî; "Asıldan çıkarılmasını gerektirecek nakli bir delilin bulunmaması hâlinde lafzın gerektiği hal üzere bırakılmasıdır." şeklinde tarif ettiği istıshâbu'l hâl/istıshâbu'l asl deliline örnek olarak da emir fiilin mebnî olduğunu, zira fiillerde asıl olanın mebnîlik olduğu hususunu göstermiștir. ${ }^{98}$ Nahiv bilginlerinin istıshâb deliliyle istidlalde bulundukları meselelerin sayısı hayli çoktur. Şöyle ki, Basra ekolü mensubu nahiv bilginleri harf-i cerlerin lafızda bir karşılığı olmaksızın hazfedilmeleri hâlinde amel etmemelerinin asıl olduğuna kânidirler. Yine onlar, " $"$ " in terkip hâlinde olmayıp yalın halde oluşunu, isimlerin âmil olmayıp fiillerin âmil oluşunu asıl saymışlardır. Ahfeş'in yanı sıra Kûfe ekolü mensubu nahiv

93 Enbârî, el-İnsâf, 1/48, 49; İbn Yaîș, Şerhu'l-mufassal, 2/228-229.

94 Birinci meseleden kasıt, isim cümlesindeki haberin ism-i fâil veya sıfat-ı müşebbehe gibi sıfat grubunda yer alan bir kelime olması hâlinde, mübtedaya dönen bir zamiri içerip içeremeyeceği meselesidir ki, parağrafın baş kısmında da belirtildiği üzere Arap dili bilginleri mübtedaya dönen bir zamiri içerebileceği noktasında icmâ etmişlerdir.

95 İkinci meseleden kasıt ise, isim cümlesindeki haberin sıfat değil de camid isim olması durumunda, haberde mübtedaya dönen bir zamirin olup olamayacağı meselesidir ki, bu konuda iki ekol ihtilaf etmiş olup belirtildiği üzere Kûfeli dil bilginleri böyle bir zamirin olabileceği, Basralı dil bilginleri ise olamayacağı noktasında fikir beyan etmişlerdir.

96 İbnu'l-Verrâk, 'İlelu'n-nahv, 202; Şâtıbî, el-Makâsıdu'ş-şâfiye, 2/70-71.

97 Şâtıbî, el-Makâsıdu'ş-şâfiye, 2/71.

98 Enbârî, el-İğrâb fî cedeli'l-i'râb, 46. 
bilginleri de "لَوْْلَكَ" (sen olmasaydın) ibaresindeki zamirin zahir ismin yerini tutması nedeniyle merfu olduğunu, dolayısıyla zamirlerde asıl olanın merfuluk olduğunu söylemişlerdir. 99 İbn Mâlik de "كَانَ" (idi) ve kardeşlerinin bir olaya, bir eyleme dela-

let etmediğini söyleyenlerin bu sözlerinin makbul olmadığını, zira bütün fiillerin zaman ve olay gibi iki anlama delalet etmesinin asıl olduğuna işaret etmiștir. ${ }^{100}$ Ayrıca; harekeyi gerektiren bir durum olmadıkça mebnîlikte asıl olanın sükûn olması, zıddına delil getirilmedikçe harflerde asıl olanın ziyade kabul etmemeleri, isimlerde asıl olanın munsarıf, nekre, müzekker, mûrab olmaları ve izafet ile isnâdı kabul etmeleri gibi hususlar bu konuya gösterilebilecek diğer örneklerdir. ${ }^{101}$

Kemâleddîn el-Enbârî istishâb delilinin muteber delillerden olduğunu söylemekle birlikte delillerin en zayıfı olduğunu ve başka bir delil bulunması hâlinde istishâb deliliyle istidlâlde bulunmanın caiz olmadığını sözlerine eklemiştir. ${ }^{102} \mathrm{Bu}$ nedenle istishâb delilinin sema veya kıyas gibi daha muteber bir delille çatışma arz etmesi hâlinde ona itibar edilmeyip karşıt delilin alınması, nahiv usulünün tercih yöntemlerinden kabul edilmiştir. ${ }^{103}$ Zira istıshâb ile istidlalde bulunmak ancak başka bir delil bulunmadığı zaman geçerli olmaktadır. ${ }^{104}$ Bir diğer ifadeyle istıshâb; nahivcilerin türettiği aklî bir delil olup ne fasih konuşan arapların sözünün önüne geçebilir, ne de arapların sözüne dayanan bir kıyas delilinin önüne geçebilir. ${ }^{105}$ Belki de bu nedenle İbn Cinnî istıshâb delilini nahvin aslî kaynakları arasında zikretmemiş, delilleri sema, kıyas ve icmâ ile sınırlı tutmuştur. ${ }^{106}$

Nahiv yöntembilimi gereğince istıshab delilinin nakil ve kıyas gibi kendisinden daha üstün bir delil ile tearuz etmesi hâlinde sema ve kıyasın gerektirdiği hüküm esas alınmalıdır. Zira bu iki aslın desteklediği görüşler muhalif fikirlerden daima daha saygın bir konumda yer almaktadır. ${ }^{107}$ Örneğin yukarıda İsimlerde asıl olanın mûrablık, fiillerde ise mebnîlik olduğu ifade edilmiști. Bu husus isimlerde binayı, fiillerde ise irabı gerektirecek harici bir delil hâsıl oluncaya kadar geçerlidir. İsimlerde mebnîliği zorunlu kılacak hâlin örneği, ismin harfe benzemesi ya da harf manası içermesidir. Mesela, "أَلَّذِي" (öyle ki) harfe benzeyen bir isim, "كَيْنَ" (nasıl?) ise harf manasını içeren bir isimdir. Fiillerde mûrablığı bağlayıcı kılacak keyfiyet

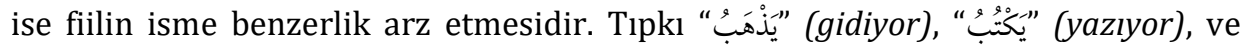
"ِ-رْكَبْ (biniyor) muzari fiillerinde olduğu gibi ${ }^{108}$... Bu hususlar, istıshâb delilinin kıyas deliline muarız olduğu hallere örnektir. Zira bu örneklerde ismin harfe, fiilin

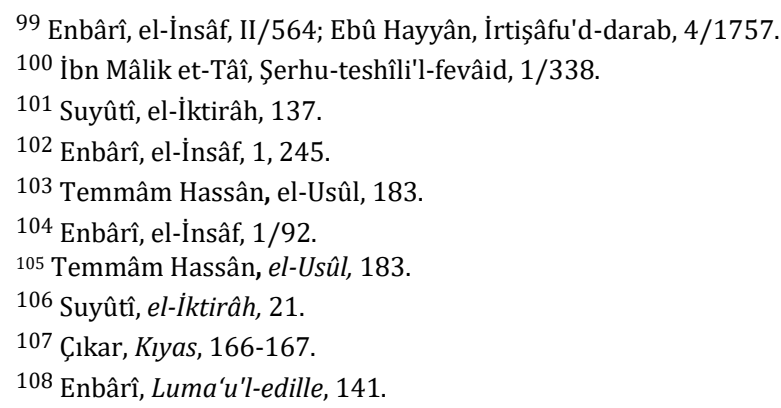


de isme kıyaslanması söz konusudur. İstıshâb delilinin semaya muarız olduğu hale ise şu örneği vermek mümkündür: İsimlerin irabında asıl olan damme ile merfu, fetha ile mansûb, kesra ile mecrûr olmalarıdır. Ancak müennes isimlerin "ات" ziyadesiyle çoğul formuna büründüğü cemi müennes salimler; damme ile merfu, kesra ile mecrûr olurken, yine kesra ile mansûb olmaktadırlar. Buna göre cemi müennes sâlimlerin mansûbluk halleri aslın dışına çıkmıștır. Zira konuyla ilgili nakil kategorisinin en mühimi olan Kur'ân'ın şu ve benzeri ayetlerinin önceliği söz konusu-

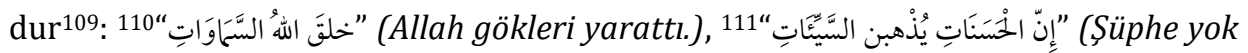
ki güzel işler, kötülükleri giderir.).

İstıshâb delilinin kendisinden daha üstün bir delile aykırılık arz ettiği, bir diğer ifadeyle nahivde aslın dışına çıkan durumlara dair başka örnekleri de anmak mümkündür. İsimlerin nekre, munsarıf, müzekker gibi aslî hallerden sıyrılıp marifelik, ğayrı munsarıflık ve müenneslik gibi arızî vasıfları haiz olmaları; beş ismin çoğullarının damme, fetha ve kesra gibi harekeler yerine "و" ile merfu, "I" ile mansûb, "ي" ile mecrûr kılınmaları ve mebnîlikte sükûn olma durumu asıl iken, harekeyle mebnîliğin arız olduğu haller bunlardan sadece birkaçıdır. ${ }^{112}$

Son olarak bu çalışmada buraya kadar nahiv ilminin öncül kaynaklarının birbiriyle çatışma arz etmesi hâlinde usul açısından takip edilecek yöntem, tespit edilmeye ve örneklendirilmeye çalışılmıştır. Söz konusu ölçütlerle ilgili örnekler bu kadarıyla sınırlı olmayıp nahiv eserlerinde daha nicelerine rastlamak mümkündür.

\section{Sonuç}

Araştırmada ulaşılan sonucu kısaca şöyle izah etmek mümkündür:

Nahvin asıllarından olan nakil ile nakil gibi aynı cinste ve kuvvette iki argümanın meselenin hükmünü zıt yönde etkilediği hallerde, nahiv usulcüleri tarafından bir tercih yöntemi olarak senet ve metin kritiğine gidildiği görülmüştür. Buna göre; senet tenkidi bağlamında ravilerin niceliğinin, tabakalarının ve yetkinliğinin, metin tenkidi bağlamında ise delillerden birinin kıyas gibi mertebesi güçlü bir diğer delille hüküm bakımından desteklenip desteklenmediği hususunun tercihin yönünü doğrudan etkilediği gözlenmiştir. Bu iki kritiğin tearuz meselesinin çözümünde yeterli olmadığı hallerde ise, yine bir tercih usulü olarak iki nakilden insanlar arasında daha meşhur olanına eğilim gösterildiği tespit edilmiştir. Aynı cins ve kuvvetteki delillerin çatışma şeklinin bir diğer örneği olan kıyas ile kıyasın karşı karşıya gelmesi hâlinde de, yine delillerden birinin bir nakille ya da yine aynı cinsten bir kıyasla takviye edilip edilmediğinin, usulcüler nezdinde bir çare olarak görüldügünü söylemek mümkündür. Yine sahih nakil ile kıyasın çelişkili olması hâlinde sahih naklin, hükmü üzerinde uzlaşım sağlanılmış mesele ile ihtilaf edilmiş mesele zıt kutuplarda yer aldığında icmâ edilmiş konunun öncelenmesinin usul

109 İbn Hişâm, Şerhu Şuzûri'z-zeheb, 66.

110 Ankebût 29/44.

111 Hûd 11/144.

112 Bk. İbn Hişâm, Şerhu Șuzûri'z-zeheb, 67; Şâtıbî, el-Makâsıdu'ş-şâfiye, 1/126. 
bilginlerince bir metot olarak tayin edildiğini dile getirmek de mümkündür. Arap dili bilginlerinin delillerin en zayıfı olarak nitelediği istishab ile istidlalde bulunmanın; ancak daha güçlü bir dayanak bulunmadığı zaman geçerli olduğu, nakil veya kıyas gibi kendisinden daha muteber bir kanıtla çatışması hâlinde arka planda kaldığı, bunun da nahiv bilginlerince "aslın dışına çıkan durum" olarak nitelendiği göze çarpan bir diğer husustur.

Arap dili bilginleri naklin diğer delillere nispetle üstün bir konuma sahip olduğu ilkesini prensipte benimsemiş olsalar da, pratikte bazı dilcilerin akıl yürütme metotlarıyla ulaştıkları ve bağlayıcılığını genel geçer saydıkları kimi kuralları kıraatlere önceleyerek bazen bu ilkeye aykırı tutum sergiledikleri görülmüştür. Yine Kufe ekolüne mensup dilcilerin, söyleyeni bilinmeyen veya söyleyeninden başkasına atfedilmiş ya da adalet ve zabt açısından kusurlu sayılmış ravilerce rivayet edilmiş şiirlerle istidlalde bulunduğu hususunda eleștirilere tabi tutulduğu da aktarılmıştır. Bütün bunlara karşın nahiv kitaplarının satır aralarına dağılmış şekilde, yukarıda yer verilen metodolojik ilkelerle uyum sağlayan çok sayıda örneğe şahit olduğumuzu da belirtmeliyiz.

Funding / Finansman: This research received no external funding. / Bu araştırma herhangi bir diş fon almamıștır.

Conflicts of Interest / Çıkar Çatışması: The author declare no conflict of interest. / Yazar, herhangi bir çıkar çatışması olmadı̆̆ını beyan eder.

\section{Kaynakça}

Benli, Ali. "Ebû İshâk Eş-Şâtıbî'de Nahiv Usûlü". İstanbul: Marmara Üniversitesi, Sosyal Bilimler Enstitüsü, Doktora tezi, 2013.

Cürcânî, Ali b. Muhammed b. Ali ez-Zeynu'ş-Şerîf. Kitâbu't-Ta'rîfât. Beyrut: Dâru'l-Kutubi'lIlmiyye, 1. Basım, 1403/1983.

Çıkar, Mehmet Şirin. "Kıyas-Bir Nahiv Usul İlmi Kaynağı”. Ankara: Akademisyen Kitabevi, 2. Basım, 2019.

Ebû Hayyân, Muhammed b. Yusuf el-Endelüsî. Irtişâfu'd-darab min lisâni'l-'Arab. thk. Recep Osman Muhammed. 5 Cilt. Kahire: Mektebetu'l-Hancî 1. Basım, 1418/1998.

Ebu'l-Mekârim, Ali. Usûlü't-tefkîri'n-nahvî. Mısır: Dâru Ğarîb li't-Tabâati ve'n-Neșr-i ve'tTevzî', 2007.

Ebu Muhammed, Bedrettin Hasan b. Kasım b. Abdillah b. Ali el-Murâdî el-Mısrî el-Mâlikî. Tavdîhu'l-makâsıd ve'l-mesâlik bi șerhi elfiyeti İbn Mâlik. thk. Abdurrahman Ali Süleyman. 3 Cilt. Mısır: Dâru'l-Fikri'l-Arabî, 1. Basım, 1428/2008.

Efğânî, Saîd. Fî usûli'n-nahv. Beyrut: el-Mektebu'l-İ́slâmî, 1407/1987.

Ekizer, Duran. "Sa'duddîn et-Teftâzânî'nin (ö.792/1390) Şerhu Dîbâceti'l-Misbâh Adlı Risalesinin Tahkiki ve Nahiv Açısından Değerlendirilmesi". Ankara Üniversitesi Ilahiyat Fakültesi Dergisi 62 (2021), 353-354.

el-Enbârî, Ebu'l-Berekât Abdurrahman b. Muhammed b. Ubeydullah el-Ensârî Kemâleddin b. Muhammed. el-İğrâb fî cedeli'l-i'râb. thk. Sa'id el-Efğanî. Dımeșk: Dâru'l-Fikr, ts.

el-Enbârî, Ebu'l-Berekât Abdurrahman b. Muhammed b. Ubeydullah el-Ensârî Kemâleddin b. Muhammed. el-İnsâf fî mesâili'l-hilâf beyne'n-nahviyyîn el-basriyyîn ve'l-kûfiyyîn. Beyrut: el-Mektebetu'l-Asriyye, 1. Basım, 1424-2003.

el-Enbârî, Ebu'l-Berekât Abdurrahman b. Muhammed b. Ubeydullah el-Ensârî Kemâleddin b. Muhammed. Luma'u'l-edille. thk. Sa'id el-Efğanî. Dımeșk: Dâru'l-Fikr, ts.

Fârisî, Ebû Ali. el-Mesâilu'l-Halebiyyât. thk. Hasan Hendâvî. Dımeşk: Dâru'l-Kalem li't-Tabâati 
ve'n-Neşr-i ve't-Tevzî', 1. Basım, 1407/1987.

Ferrâ, Ebû Zekeriyya Yahya b. Ziyâd b. Abdillah b. Manzûr ed-Deylemî. Me'âni'l-Kur'ân. thk. Ahmet Yusuf en-Necati ve diğerleri. 3 Cilt. Mısır: Dâru'l-Mısriyye li't-te'lif ve'tTerceme, 1. Basım, ts.

Hasan, Abbâs. en-Nahvu'l-vâfí. Kâhire: Dâru'l-Maârif, 15. Basım, ts.

Hulvânî, Muhammed Hayr. Usûlü'n-nahvi'l-Arabî. Rabat: en-Nâşir el-Atlasî, 1983.

İbn Akîl, Abdullah b. Abdurrahman el-'Ukaylî el-Hemedânî el-Misrî. Şerhu İbn Akîl 'alâ elfiyeti İbn Mâlik. thk. Muhammed Muhiddin Abdülhamid. 4 Cilt. Kâhire: Dâru'tTurâs, 20. Basım, 1400/1980.

İbn Cinnî, Ebû'l-Feth Osman el-Mavsılî. el-Hasâis. 3 Cilt. Kâhire: el-Hey'etu'l-Mısriyyetu'lÂmme li'l-Kitâb, 4. Basım, ts.

İbn Cinnî, Ebû'l-Feth Osman el-Mavsılî. el-Muhtesib fî tebyîni vucûhi șevâzzi'l-kıraâti ve'lîdâhi anhâ. 2 Cilt. Mısır: Vizârâtu'l-Evkâf-el-Meclisu'l-A'lâ li'ş-Şuûni'l-İslâmiyye, $1420 / 1999$.

İbn Cinnî, Ebû'l-Feth Osman el-Mavsılî. el-Luma' fi'l-Arabiyye. thk. Fâiz Fâris. Kuveyt: Dâru'lKutubi's-Sekâfiyye, ts.

İbnu'l-Esîr, Mecduddîn Ebu's-Saâdât el-Mubarek b. Muhammed. el-Bedî' fì 'Ilmi'l-Arabiyye. thk. Fethî Ahmed Aliyyüddin. 2 Cilt. Mekke: Câmiatu Ummu'l-Kurâ, 1.Basım, 1420.

İbn Hâleveyh, Ebû Abdillâh el-Hüseyn b. Ahmed. Muhtasar fí șevâzzi'l-Kur'ân min Kitâbi'lBedî́. Kâhire: Mektebetu'l-Mutenebbî, ts.

İbn Hişâm, Ebû Muhammed Cemaleddin Abdullah b. Yusuf. Evdahu'l-mesâlik ilâ Elfiyyeti İbn Mâlik. thk. Yusuf eș-Şeyh Muhammed el-Bekâ'î. Dımeșk: Dâru'l-Fikr li't-Tabâati ve'nNeşr ve't-Tevzî', ts.

İbn Hişâm, Ebû Muhammed Cemaleddin Abdullah b. Yusuf. Muğni'l-lebîb an kutubi'l-e'ârîb. thk. Mâzini'l-Mubarek-Muhammed Ali Hamdullah. 4 Cilt. Dımeşk: Dâru'l-Fikr, 6. Basım, 1985.

İbn Hişâm, Ebû Muhammed Cemaleddin Abdullah b. Yusuf. Şerhu Katru'n-nedâ ve bellu'ssadâ. thk. Muhammed Muhyiddîn Abdülhamid. Beyrut: el-Mektebetu'l-Asriyye, $1423 / 2003$.

İbn Hişâm, Ebû Muhammed Cemaleddin Abdullah b. Yusuf. Şerhu Şuzûri'z-zeheb fî ma'rifeti kelâmi'l-arab. thk. Muhammed Muhyiddîn Abdülhamid. Beyrut: el-Mektebetu'lAsriyye, 1429/2008.

İbn Hişâm, Ebû Muhammed Cemaleddin Abdullah b. Yusuf. Tahlîsu'ş-şevâhid ve telhisu'lfevâid. thk. Abbas Mustafa es-Salihî. Beyrut: Dâru'l-Kitâbi'l-Arabî, 1. Basım, 1406/1986.

İbn Mâlik et-Tâî, Ebû Abdullah Cemâlüddîn Muhammed b. Abdullah. SSerhu'l-Kâfiyeti'ş-Şâfiye. thk. Abdulmunim Ahmed Hureydî. 5 Cilt. Mekke: Câmiatu- Ümmu'l-Kurâ, 1. Basım, $1402 / 1982$.

İbn Mâlik et-Tâî, Ebû Abdullah Cemâlüddîn Muhammed b. Abdullah. Şerhu-teshîli'l-fevâid. nşr. Abdurrahman Seyyid - Muhammed Bedevî el-Mahtûn. 3 Cilt. Kahire: Hicrun li'tTabâati ve'n-Neşri ve't-Tevzi', 1. Basım, 1410/ 1990.

İbn 'Usfûr, Ali b. Mümin b. Muhammed Ebu'l-Hasen. Darairu'ş-şi'r. thk. es-Seyyid İbrahim Muhammed. Beyrut: Dâru'l-Endelus li't-Tabâati ve'n-Neșri ve't-Tevzi', 1980.

İbnu's-Serrâc, Ebû Bekr Muhammed b. es-Serî b. Sehl el-Bağdâdî. el-Usûl fi'n-nahv. thk. Abdülhüseyin el-Fetilî. 3 Cilt. Beyrut: Muessesetu'r-Risâle, ts.

İbnu'l-Verrâk, Ebû'l-Hasan Muhammed b. Abdullah. 'İlelu'n-nahv. thk. Mahmud CâsimMuhammed Dervîș. Riyâd: Mektebetu'r-Rüşd, 1. Basım, 1420/1999.

İbn Yaîș, Ebû'l-Bekâ Yaîș b. Ali. Şerhu'l-mufassal li'z-Zemahșerî. thk. Emîl Bedi' Yakub. 6 Cilt. Beyrut: Dâru'l-Kutubi'l-Ilmiyye, 1. Basım, 1422/2001.

İmîl Bedi' Ya'kûb. el-Mu'cemu'l-mufassal fí şevâhidi'l-Arabiyye. Beyrut: Dâru'l-Kutubi'lIlmiyye, 1.Basım, 1417/1996.

Menâhicu Câmiati'l- Medîneti'l-Âlemiyye. Usûlu'n-nahv. 2 Cilt. Câmiatu'l- Medîneti'lÂlemiyye: ts.

Müberred, Ebu'l-Abbâs Muhammed b. Yezîd. el-Muktedab. thk. Muhammed Abdulhâlik 
Azîme. 4 Cilt. Beyrut: Âlemu'l-Kutub, ts.

Muhammed Han. Usûlü'n-nahvi'l-Arabî. Matbaatu Câmiati Muhammed Haydar, 2012.

Nahle, Mahmud Ahmed. Usûlü'n-nahvi'l-Arabî. Beyrut: Dâru'l-Ulûmi'l-Arabiyye, 1. Basım, $1407 / 1987$.

Neccâr, Nâdiye Ramazan. el-Karâin beyne'l-luğaviyyîn ve'l-usûliyyîn. Beyrut: Dâru'l-Kutubi'lIlmiyye, 1436/2015.

Nehhâs, Ebû Câfer Ahmed b. Muhammed en-Nahvî. I'râbu'l-Kur'ân. hâșiye ve tâ'lik Abdulmunim Halil İbrahim. 5 Cilt. Beyrut: Dâru'l-Kutubi'l-Ilmiyye 1. Basım, 1421.

Suyûtî, Celâleddîn Abdurrahmân b. Ebî Bekr. Hem'u'l-hevâmi' fî şerhi cem'ı'l-cevâmi'. thk. Abdülhamit Hendâvî. 3 Cilt. Mısır: el-Mektebetu't-Tevfîkıyye, ts.

Suyûtî, Celâleddîn Abdurrahmân b. Ebî Bekr. el-İktirâh fî Usûli'n-nahv. Dımeșk: Dâru'lBeyrûtî, 2. Basım, 1407/2006.

Suyûtî, Celâleddîn Abdurrahmân b. Ebî Bekr. el-Muzhir fî ulûmi'l-luğati ve envâihâ. Fuâd Ali Mansûr. 2 Cilt. Beyrut: Dâru'l-Kutubi'l-Ilmiyye, 1. Basım, 1418/1998.

Sîbeveyh, Ebû Bişr Amr b. Osman b. Kanber. el-Kitâb. thk. Abdüsselâm Muhammed Hârun. 4 Cilt. Kahire: Mektebetu'l-Hancî, 3. Basım, 1408/1988.

Sîrâfî, Ebû Saî̂d el-Hasen İbni Abdillah. Șerhu Kitabi Sîbeveyh. thk. Ahmed Hasan Mehdelî ve Ali Seyyid Ali. 5 Cilt. Beyrut: Dâru'l-Kutubi'l-Ilmiyye, 1. Basım, 2008.

Şâtıbî, Ebû İshak İbrahim b. Musa. el-Makâsıdu'ş-şâfiye fî şerhi hulâsati'l-Kâfiye. thk. Abdurrahman b. Süleyman el-Useymîn ve diğerleri. 10 Cilt. Mekke: Câmiatu Ummi'lKurâ, 1428/2007.

Temmâm Hassân. el-Usûl (dirâse ibistîmûlûjiyye li'l-fikri'l-luğavî inde'l-arab en-nahvu fikhu'l-luğa - el-Belâga). Kahire: Â'lemu'l-kutub, 1420/2000.

'Ukberî, Ebû'l-Bekâ Abdullah b. Hüseyin. el-Lübâb fî ıleli'l-binâi ve'l-i'rab. thk. Abdülilâh enNebhân. Dımeșk: Dâru'l-Fikr, 1. Basım, 1416/1995.

'Ukberî, Ebû'l-Bekâ Abdullah b. Hüseyin. et-Tebyîn 'an mezâhibi'n-nahviyyîn el-Basriyyîn ve'lKûfiyyîn. thk. Abdurrahman el- 'Useymîn. Beyrut: Dâru'l-Ğarbi'l-İslâmî, 1. Basım, 1406/1986.

Zeccâcî, Ebû'l-Kâsım Abdurrahman b. İshak el-Bağdâdî. Mecâlisu'l-'ulemâ. thk. Abdusselam Muhammed Harun. Kahire: Mektebetu'l-Hancî, 2. Basım, 1403/1983.

Zemahşerî, Ebu'l-Kâsım Mahmud b. Amr. el-Keşşâf an hakâikı ğavâmidı't-tenzîl. 4 Cilt. Beyrut: Dâru'l-Kitâbi'l-Arabî, 3. Basım, 1407.

Zemahșerî, Ebu'l-Kâsım Mahmud b. Amr. el-Mufassal fî san'ati'l-i'râb. thk. Ali Bû Mulhim. Beyrut: Mektebetu'l-Hilâl, 1. Basım, 1993.

Zühaylî, Muhammed Mustafa. el-Vecîz fî usûli'l-fikhi'l-İslâmî. 2 Cilt. Dımeşk: Dâru'l-Hayr li'tTabâati ve'n-Neşri ve't-Tevzî', 1427/2006. 